\title{
ZINC NUTRITION IN DEVELOPING COUNTRIES
}

\author{
ROSALIND S. GIBSON
}

Division of Applied Human Nutrition, University of Guelph, Guelph, Ontario, N1G 2W1, Canada

\section{CONTENTS}

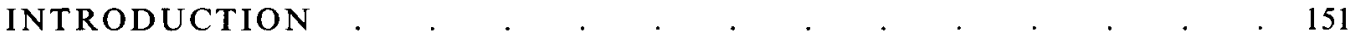

AETIOLOGY OF ZINC DEFICIENCY IN DEVELOPING COUNTRIES . 153

DIETARY FACTORS: LOW INTAKE AND POOR BIOAVAILABILITY OF

DIETARY ZINC

EXCESSIVE LOSSES . . . . . . . . . . . . . . 154

HIGH PHYSIOLOGICAL REQUIREMENTS . . . . . . . . . . . . . 154

ZINC INTAKES IN RELATION TO ESTIMATED REQUIREMENTS . . 155

LABORATORY ASSESSMENT OF ZINC STATUS . . . . . . . 157

BIOCHEMICAL INDICES OF ZINC STATUS . . . . . . . . . . . 157

PHYSIOLOGICAL FUNCTIONAL INDICES OF ZINC STATUS . . . . . 160

ZINC DEFICIENCY THROUGHOUT THE LIFE CYCLE . . . . . 160

INFANCY AND CHILDHOOD. . . . . . . . . . . . . . 160

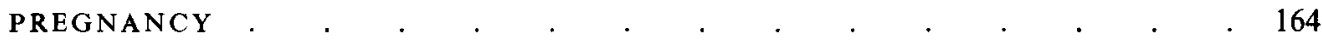

LACTATION .

NUTRITION INTERVENTION STRATEGIES TO PREVENT ZINC
DEFICIENCY IN DEVELOPING COUNTRIES . $. . \quad . \quad . \quad 167$

REFERENCES . . . . . . . . . . . . . . . 168

\section{INTRODUCTION}

Recently the United Nations has urged that priority should be given to developing programmes in less industrialized countries to prevent deficiencies of iodine, vitamin $\mathrm{A}$, and Fe (United Nations, 1991). Nutritional Fe deficiency is associated with plant based diets which contain high levels of dietary fibre and phytate, components known to inhibit nonhaem $\mathrm{Fe}$ absorption, and low levels of flesh foods, rich sources of readily available haem iron (Monsen, 1988). Such plant based diets will also induce $\mathrm{Zn}$ deficiency. The consequences of $\mathrm{Zn}$ deficiency on human health in developing countries, however, have not yet been recognized. This is unfortunate because even mild $\mathrm{Zn}$ deficiency may contribute to pregnancy complications, low birth weight, impaired immune competence, maternal and infant mortality and morbidity, and growth failure in infancy and childhood (Swanson \& King, 1987; Hambidge, 1989; National Academy of Sciences, 1991 ; United Nations, 1991). Hence $\mathrm{Zn}$ deficiency may have far reaching consequences on maternal, infant, and child health in many developing countries. 
Table 1. Zinc $\dagger$, phytic acid $\dagger$ and [phytate]:[zinc] molar ratios of some foods and composite dishes consumed in Ghana and Malawi

\begin{tabular}{|c|c|c|c|c|}
\hline Food, and scientific name or recipe & $\mathrm{Zn}$ & Phy & Phy: Zn & $\% \mathrm{H}_{2} \mathrm{O}$ \\
\hline \multicolumn{5}{|l|}{ Cereals } \\
\hline Maize flour, $95 \%$ extraction (Zea mays L.) & $2 \cdot 2$ & 792 & 36 & 10 \\
\hline Maize flour, $65 \%$ extraction & 0.9 & 211 & 23 & 10 \\
\hline Maize bran & $3 \cdot 7$ & 1089 & 29 & 10 \\
\hline Maize dough & 1.4 & n.a. & n.a. & 50 \\
\hline Sorghum flour (Sorghum bicolor (L.) Moench) & $1 \cdot 4$ & 446 & 32 & 10 \\
\hline Rice (Oryza sativa) & 1.6 & n.a. & n.a. & 10 \\
\hline \multicolumn{5}{|l|}{ Legumes } \\
\hline Ground nuts, boiled (Arachis hypogaea L.) & 1.4 & 505 & 35 & 49 \\
\hline Ground nuts, flour & $2 \cdot 8$ & 1297 & 45 & 8 \\
\hline Pigeon peas, fresh (Cajanus cajan (L.) Millsp.) & 0.9 & 255 & 27 & 63 \\
\hline Pigeon peas, dry & $2 \cdot 2$ & 727 & 33 & 8 \\
\hline Kidney beans, fresh (Phaseolus vulgaris L.) & 1.5 & 557 & 36 & 52 \\
\hline Cowpeas, boiled (Vigna unguiculata (L.) Walp.) & $1 \cdot 0$ & 349 & 37 & 68 \\
\hline Lima beans, fresh (Phaseolus lunatus L.) & 1.5 & 238 & 16 & 66 \\
\hline Bengal beans, fresh (Stizolobium aterrimum Piper \& Tracey) & $1 \cdot 0$ & 166 & 17 & 68 \\
\hline \multicolumn{5}{|l|}{ Vegetables (boiled) } \\
\hline Pumpkin leaf (Cucurbita maxima Duch. ex Lam.) & 0.7 & 34 & 5 & 89 \\
\hline Chinese cabbage (Brassica chinensis L.) & 0.7 & 5 & 1 & 94 \\
\hline Okra leaf (Hibiscus esculentus (L.)) & 1.8 & 97 & 5 & 79 \\
\hline Okra (Hibiscus esculentus (L.)) & 0.5 & 13 & 3 & 91 \\
\hline Cassava leaf (Manihot esculenta Crantz) & $1 \cdot 2$ & 42 & 3 & 78 \\
\hline Cocoyam leaves (Xanthosoma sp. Schott.) & $0 \cdot 6$ & 19 & 3 & 88 \\
\hline Amaranth leaves (Amaranth sp. L.) & $0 \cdot 3$ & n.a. & n.a. & 93 \\
\hline \multicolumn{5}{|l|}{ Roots and plantain (boiled) } \\
\hline Sweet potato (Ipomoea batatas L.) & $0 \cdot 2$ & 10 & 5 & 70 \\
\hline Yam (Dioscorea sp. L.) & $0 \cdot 3$ & 50 & 13 & 68 \\
\hline Cocoyam (Xanthosoma sp.) & 0.5 & 37 & 7 & 60 \\
\hline Cassava (Manihot sp.) & $0 \cdot 3$ & 54 & 18 & 65 \\
\hline Cassava dough, fermented & $0 \cdot 4$ & 48 & 12 & 51 \\
\hline Gari: dry fermented cassava, not boiled & $0 \cdot 7$ & 51 & 4 & 12 \\
\hline Plantain, ripe (Musa paradisiaca L.) & $0 \cdot 2$ & 0 & 0 & 73 \\
\hline Plantain, unripe (Musa paradisiaca $\mathrm{L}$.) & $0 \cdot 2$ & 1 & 1 & 65 \\
\hline Water yam (Dioscorea alata $\mathbf{L}$.) & $0 \cdot 2$ & 26 & 16 & 72 \\
\hline \multicolumn{5}{|l|}{ Fruits } \\
\hline Avocado pear (Persea americana Mill.) & $0 \cdot 3$ & 11 & 3 & 78 \\
\hline Banana (Musa paradisiaca L.) & $0 \cdot 2$ & 22 & 9 & 72 \\
\hline Mango, raw (Mangifera indica L.) & $0 \cdot 1$ & 25 & 23 & 82 \\
\hline \multicolumn{5}{|l|}{ Composite dishes - home-prepared snacks } \\
\hline $\begin{array}{l}\text { Chitumbuwa (mixture of water, maize flour and pounded } \\
\text { bananas formed into a round cake and fried in oil) }\end{array}$ & $1 \cdot 2$ & 504 & 42 & 30 \\
\hline $\begin{array}{l}\text { African bread (mixture of water, maize flour and bananas formed } \\
\text { into a cake, wrapped in banana leaves and boiled until cooked) }\end{array}$ & $0 \cdot 3$ & 102 & 37 & 70 \\
\hline $\begin{array}{l}\text { African cake (mixture of water, maize flour and sugar baked in } \\
\text { tin can) }\end{array}$ & $1 \cdot 2$ & 297 & 26 & 45 \\
\hline \multicolumn{5}{|l|}{ Composite dishes - staples } \\
\hline Hausa porridge (thin porridge of corn flour) & $0 \cdot 1$ & 25 & 25 & 94 \\
\hline Porridge of corn grits & $0 \cdot 1$ & 23 & 23 & 88 \\
\hline Banku (boiled mixture of corn dough and cassava dough) & $0 \cdot 7$ & 107 & 16 & 73 \\
\hline $\begin{array}{l}\text { Ga kenkey (corn dough made into dumplings and boiled in } \\
\text { banana leaves) }\end{array}$ & $0 \cdot 8$ & 172 & 19 & 71 \\
\hline $\begin{array}{l}\text { Fanti kenkey (corn dough made into dumplings and boiled in } \\
\text { plantain leaves) }\end{array}$ & $0 \cdot 7$ & 118 & 21 & 72 \\
\hline Fufu (pounded boiled cassava and plantain) & 0.4 & 96 & 24 & 69 \\
\hline
\end{tabular}


Table 1 (cont.)

\begin{tabular}{lcccc}
\hline \hline Food, and scientific name or recipe & $\mathrm{Zn}$ & $\mathrm{Phy}$ & $\mathrm{Phy}: \mathrm{Zn}$ & $\% \mathrm{H}_{2} \mathrm{O}$ \\
\hline Rice and stew (rice and standard ingredientsł) & 0.6 & 118 & 21 & 68 \\
Rice and beans (rice, cowpeas and standard ingredients) & 0.5 & 107 & 18 & 70 \\
Gari and beans (gari, cowpeas and standard ingredients) & 0.9 & 178 & 22 & 59 \\
Composite dishes - soups & & & & \\
$\quad$ Palmnut soup (water, palmnut cream and standard ingredients) & 0.4 & n.a. & n.a. & 86 \\
$\quad$ Groundnut soup (water, groundnut paste and standard ingredi- & 0.8 & 81 & 10 & 88 \\
$\quad$ ents) & & & & \\
Composite dishes - stews & 0.4 & 38 & 9 & 90 \\
$\quad$ Okra (okra and standard ingredients) & 0.7 & n.a. & n.a. & 72 \\
Bean (cowpeas and standard ingredients) & & &
\end{tabular}

$\dagger, \mathrm{mg} / 100 \mathrm{~g}$ wet weight. n.a., not analysed.

$\$$, standard ingredients: tomato, red peppers, salt, onion, fish; palm oil in stews, rice and beans, and gari and beans.

Phy: Zn, [phytate]/[Zn] molar ratios. Phytate was analysed by the standard AOAC method (Harland \& Oberleas, 1986).

All data from Ferguson et al. $(1988,1989 b, 1993 a)$.

\section{AETIOLOGY OF ZINC DEFICIENCY IN DEVELOPING COUNTRIES}

\section{DIETARY FACTORS: LOW INTAKE AND POOR BIOAVAILABILITY OF DIETARY ZINC}

The nutritional adequacy of dietary $\mathrm{Zn}$ depends on both its amount and bioavailability in the diet. Flesh foods are a rich source of $\mathrm{Zn}$ which is readily available because during their digestion certain L-amino acids and cysteine-containing peptides are released, which form soluble ligands with $\mathrm{Zn}$ (Sandström et al. 1980, 1989). In many developing countries, however, the content of flesh foods in rural diets is often low so that their contribution to total dietary $\mathrm{Zn}$ intake is small. Instead, diets are mainly plant based; cereals, starchy roots and/or tubers are often the major sources of $\mathrm{Zn}$ in rural diets. Of these staples, starchy roots and tubers generally have a lower $\mathrm{Zn}$ content than cereals, as shown by the Ghanaian and Malawian examples shown in Table 1. Hence, diets based on these staples tend to be correspondingly lower in $\mathrm{Zn}$ than cereal based diets (Gibson et al. $1991 \mathrm{a}$; Ferguson et al. 1993a). Nevertheless, in certain geographical areas where $\mathrm{Zn}$ deficient soils exist, cereal staples will have a lower $\mathrm{Zn}$ content than when grown on $\mathrm{Zn}$ sufficient soils.

Plant based diets often contain high levels of phytic acid (myoinositol hexaphosphate) and dietary fibre, components known to inhibit the absorption of dietary $\mathrm{Zn}$ (Sandström, 1989). Of these antinutrients, phytic acid (Phy), the major storage form of phosphorus in cereals, legumes, and oleaginous seeds, is the most potent inhibitor of $\mathrm{Zn}$ absorption (Sandström \& Lönnerdal, 1989). It forms insoluble chelates at a physiological $\mathrm{pH}$. The lower inositol phosphates (i.e. tetra-, tri-, di-, and mono-inositol phosphates), formed by enzymic or non-enzymic hydrolysis of phytic acid, do not form insoluble complexes with $\mathrm{Zn}$ (Lönnerdal et al. 1989). The bioavailability of dietary $\mathrm{Zn}$ can be predicted from the ratio of phytic acid [Phy] to zinc [Zn] in diets. The critical [Phy]: $[\mathrm{Zn}]$ molar ratios associated with risk of $\mathrm{Zn}$ deficiency are equivocal; ratios above 15 have been associated with biochemical (Harland \& Peterson, 1978; Oberleas \& Harland, 1981; Turnlund et al. 1984; Bindra et al. 1986), and in some cases clinical signs of $\mathrm{Zn}$ deficiency in humans (Ferguson et al. 1989a). 
Plant based staples such as unrefined maize flour, brown rice, sorghum and certain legumes (e.g. groundnuts, pigeon peas, kidney beans, and cowpeas) have elevated [Phy]:[Zn] molar ratios (Table 1; Ferguson, 1992). Hence, diets based on cereals and legumes have higher [Phy]:[Zn] molar ratios than those based on starchy roots and/or tubers (Ferguson et al. 1993a; Fitzgerald et al. 1993).

High levels of calcium potentiate the inhibitory effect of phytate on $\mathrm{Zn}$ absorption by forming a $\mathrm{Ca}: \mathrm{Zn}$ :phytate complex that is even less soluble than phytate complexes formed by either ion alone (Wise, 1983). Hence, some authors have proposed that dietary [Phy][Ca]: $[\mathrm{Zn}]$ ratios may be a better predictor of $\mathrm{Zn}$ bioavailability than [Phy]:[Zn] ratios alone (Davies et al. 1985; Fordyce et al. 1987). To date, the critical [Ca][Phy]:[Zn] molar ratio that compromises $\mathrm{Zn}$ bioavailability in human diets has not been clearly defined. Retrospective calculations of experimental data from Cossack \& Prasad (1983) suggest that molar ratios above $0.2(200 \mathrm{mmol})$ may be associated with decreased $\mathrm{Zn}$ bioavailability in human diets. Most plant based diets are low in $\mathrm{Ca}$, however, with the exception of those based on tortillas (Fitzgerald et al. 1993). The latter contain a relatively high concentration of $\mathrm{Ca}$, derived from lime used to soak the maize in the preparation of nixtamal (soaking of corn kernels to liberate the husks) before being milled into masa (raw corn dough). Diets of lacto-ovo vegetarians may also have elevated [Ca][Phy]:[Zn] molar ratios (Bindra et al. 1986).

Dietary fibre, notably the insoluble fibres cellulose and lignin, may also inhibit $\mathrm{Zn}$ absorption to some degree, although their effects are equivocal, in part because fibre generally occurs concomitantly with phytic acid, making any independent inhibitory effect difficult to establish (Torre et al. 1991).

The bioavailability of $\mathrm{Zn}$ can also be affected by competitive interactions among certain micronutrients in the intestine, notably between $\mathrm{Zn}$ and non-haem $\mathrm{Fe}$, and $\mathrm{Zn}$ and copper (Mills, 1985). The Fe and $\mathrm{Cu}$ contents of most human diets, however, are generally not high enough to compromise $\mathrm{Zn}$ bioavailability, unless high doses of supplemental non-haem iron are used (Solomons, 1986). In some cases, a negative Fe- $\mathrm{Zn}$ interaction has not been observed when the $\mathrm{Fe}$ is mixed with or is present as an intrinsic part of a food or meal (Valberg et al. 1984). Some (Milne et al. 1984; Mukherjee et al. 1984) but not all (Butterworth et al. 1988; Krebs et al. 1988) researchers have also observed a negative effect of high doses of folate supplements on $\mathrm{Zn}$ status, which could be of significance for pregnant women prescribed both supplemental folate and non-haem iron.

\section{EXCESSIVE LOSSES}

Additional factors that may exacerbate suboptimal $\mathrm{Zn}$ status in population groups living in developing countries include increased endogenous losses of $\mathrm{Zn}$ through perspiration; exfoliation of the skin as a result of the hot, humid climate; chronic haemolysis due to genetic factors (e.g. $\alpha$-thalassaemia, sickle cell disease) and/or parasite infections (e.g. malaria, hookworm, schistosomiasis), and diarrhoea (Solomons, 1981; Ruz \& Solomons, 1990). Ferguson (1992) estimated urinary $\mathrm{Zn}$ losses from haemolysis induced by schistosomiasis to range from 0.02 to $0.85 \mathrm{mg} / \mathrm{d}$; faecal losses of $\mathrm{Zn}$ in infants with chronic diarrhoea can be as high as $300 \mu \mathrm{g} / \mathrm{kg}$ daily (Rothbaum et al. 1982). In areas where geophagia is practised, extensive faecal losses arising from poor absorption of dietary $\mathrm{Zn}$ may exacerbate $\mathrm{Zn}$ deficiency (Prasad et al. 1963).

\section{HIGH PHYSIOLOGICAL REQUIREMENTS}

The FAO/WHO/ILEA committee are currently revising the $\mathrm{Zn}$ requirements to include estimates to meet both basal and normative requirements (FAO/WHO/ILEA, un- 
published observations, 1992). Basal requirements are the amount needed to prevent clinically detectable signs of functional impairment whereas the normative requirement represents the amount needed to maintain tissue stores or reserve capacity.

Physiological requirements of $\mathrm{Zn}$ are increased during periods of rapid growth because it has such a critical role in nucleic acid synthesis and protein metabolism. Hence, infants and children are especially vulnerable to $\mathrm{Zn}$ deficiency. In infants in developing countries, $\mathrm{Zn}$ stores at birth may be small as a consequence of their low birth weight and poor nutritional status of the mothers. Therefore, their dietary requirements for catch-up growth will be higher than those of infants from industrialized countries.

Male infants and children appear to have higher requirements for $\mathrm{Zn}$ than females, because of their higher growth rates and greater proportion of muscle $/ \mathrm{kg}$ body weight; muscle contains a higher content of $\mathrm{Zn}$ than fat (Giugliano \& Millward, 1984). In several double-blind supplementation studies, males have exhibited greater improvements in rate of linear growth and/or weight gain than their $\mathrm{Zn}$ supplemented female counterparts (Walravens \& Hambidge, 1976; Walravens et al. 1983, 1989; Castillo-Duran et al. 1987; Schlesinger et al. 1992; M. Ruz, 1993, pers. comm.).

Requirements for $\mathrm{Zn}$ are also greater during pregnancy and lactation for the growth and development of the fetus and maternal tissues, and secretion of breast milk. The FAO/ WHO/ILEA committee (unpublished, 1992) calculated the average individual physiological requirements for absorbed $\mathrm{Zn}$ during each trimester of pregnancy to be $0 \cdot 8,1 \cdot 0$, $1.4 \mathrm{mg} / \mathrm{d}$ for the basal requirements and $1.1,1.4$, and $2.0 \mathrm{mg} / \mathrm{d}$ for the normative requirements. These estimates do not take into account differences in the absorbability of dietary $\mathrm{Zn}$ or the varied intakes within the population. During the course of lactation, $\mathrm{Zn}$ concentrations in human milk decline (Casey et al. 1989). Hence, estimates of the average individual basal requirement range from 1.6 at $0-3$ months and 1.5 at 3-6 months to $1.2 \mathrm{mg} / \mathrm{d}$ between 6 and 12 months; corresponding estimates for normative requirements are $1.9,1.8$, and $1.5 \mathrm{mg} / \mathrm{d}$ respectively (FAO/WHO/ILEA, unpublished observations, 1992).

\section{ZINC INTAKES IN RELATION TO ESTIMATED REQUIREMENTS}

In many developing countries, information on intakes and major food sources of $\mathrm{Zn}$ in local diets, as well as on the antinutrients dietary fibre and phytate, are limited, in part because of the paucity of data on the content of $\mathrm{Zn}$ and antinutrients in local foodstuffs. This is unfortunate because such data are essential for assessing the risk for inadequate intakes of dietary $\mathrm{Zn}$, and for planning dietary strategies to improve its content and bioavailability in traditional diets.

Population groups consuming diets based predominantly on unrefined maize and rice generally have markedly higher intakes of phytate and elevated [Phy]:[Zn] molar ratios compared to those consuming diets based on starchy roots and/or tubers (Table 2) (Mbofung \& Atinmo, 1987; Gibson et al. $1991 a$; Ferguson et al. 1993b; Fitzgerald et al. 1993). The latter, however, often have lower $\mathrm{Zn}$ intakes. Molar ratios of [Ca][Phy]: $[\mathrm{Zn}]$ in most of these plant based diets are low with the exception of those based on tortillas (Fitzgerald et al. 1993).

The adequacy of dietary $\mathrm{Zn}$ intakes can be evaluated by comparison with the newly revised requirements, provided an estimate of the bioavailability of $\mathrm{Zn}$ in the diet can be made. Diets can be categorized as high, moderate, or low in terms of $\mathrm{Zn}$ bioavailability, based on their content of animal or fish protein, calcium, and [Phy]:[Zn] molar ratios (FAO/WHO/ILEA, unpublished observations, 1992). Alternatively, more direct measure- 
Table 2. Dietary intakes (mean $\pm S D$ ) of zinc, phytate, phytate:zinc molar ratios, and dietary fibre of children in some developing countries

\begin{tabular}{|c|c|c|c|c|}
\hline $\begin{array}{c}\text { Country (n) Age in years } \\
\text { Reference }\end{array}$ & Zinc (mg/day) & Phytate (mg/day) & Phy:Zn & $\begin{array}{l}\text { Dietary fibre } \\
\text { (g/day) }\end{array}$ \\
\hline $\begin{array}{l}\text { Papua New Guinea (67) 6-10 } \\
\text { Gibson et al. } 1991 \text { a }\end{array}$ & $4 \cdot 4 \pm 1 \cdot 3$ & $646 \pm 663$ & 12 & $37 \cdot 1 \pm 11 \cdot 4$ \\
\hline $\begin{array}{l}\text { Malawi (67) 4-6 } \\
\text { Ferguson et al. } 1993 b\end{array}$ & $6.6 \pm 1 \cdot 7$ & $1899 \pm 590$ & 25 & $24.9 \pm 6.4 \dagger$ \\
\hline $\begin{array}{l}\text { Ghana (148) 3-6 } \\
\text { Ferguson et al. } 1993 b\end{array}$ & $4 \cdot 7 \pm 1 \cdot 1$ & $591 \pm 153$ & 13 & $15 \cdot 5 \pm 3 \cdot 8 \dagger$ \\
\hline $\begin{array}{l}\text { Egypt (96) } 1 \cdot 5-2 \cdot 5 \\
\text { Murphy et al. } 1992\end{array}$ & $5 \cdot 2 \pm 1 \cdot 6$ & $796 \pm 249$ & 16 & $17 \cdot 4 \pm 5 \cdot 9$ \\
\hline $\begin{array}{l}\text { Kenya (100) } 1 \cdot 5-2 \cdot 5 \\
\text { Murphy et al. } 1992\end{array}$ & $3 \cdot 7 \pm 0 \cdot 9$ & $1066 \pm 324$ & 28 & $21 \cdot 6 \pm 5 \cdot 5$ \\
\hline $\begin{array}{l}\text { Mexico (59) } 1.5-2.5 \\
\text { Murphy et al. } 1992\end{array}$ & $5 \cdot 3 \pm 1 \cdot 3$ & $1666 \pm 650$ & 30 & $15 \cdot 3 \pm 4 \cdot 8$ \\
\hline $\begin{array}{l}\text { Guatemala (136) 6-8 } \\
\text { Cavan et al. } 1993 a\end{array}$ & $9 \cdot 0+$ & $962 \dagger$ & 11 & $14 \cdot 0 \ddagger$ \\
\hline $\begin{array}{l}\text { Canada (106) 4-6 } \\
\text { Gibson et al. } 1991 b\end{array}$ & $6 \cdot 9 \pm 2 \cdot 3$ & $(300) \ddagger$ & 5 & $11 \cdot 4 \pm 5 \cdot 5$ \\
\hline
\end{tabular}

$\dagger$ Non-starch polysaccharide.

+ Median.

ments of the bioavailability of $\mathrm{Zn}$ in local diets can be made by using radioactive or stable isotope techniques (Sandström \& Lönnerdal, 1989).

Some studies report average $\mathrm{Zn}$ intakes for a specific population group (Mbofung \& Atinmo, 1987), often based on one day's intake per individual. Such data do not take into account the distribution of intakes among individuals and cannot be used to estimate the proportion of individuals within the population at risk for nutrient inadequacy. For the latter, food intake data based on at least two days' intake per person are required. If single days are used, prevalence estimates for risk of inadequacy are always too high (Beaton, 1985). To improve the reliability of the prevalence estimates for dietary inadequacy, they should be determined using the probability approach recommended by the Subcommittee for Criteria for Dietary Evaluation (National Research Council, 1986). When this approach has been used in studies of dietary $\mathrm{Zn}$ intakes of children in developing countries, a very high proportion of the children studied from Kenya and Malawi $(>90 \%)$, and more than two-thirds from Mexico and Ghana, were apparently at risk, assuming that the estimates used for both the bioavailability and basal requirements for $\mathrm{Zn}$ are valid (Murphy et al. 1992; Ferguson et al. 1993b).

Even the $\mathrm{Zn}$ intakes of exclusively breast fed infants may be inadequate during the first 4-6 months in some developing countries, especially if the infants are preterm and/or of low birth weight with high nutrient demands for catch-up growth. Moreover, their supply of $\mathrm{Zn}$ from breast milk may be compromised by the poor nutritional status of the lactating mothers, which may result in breast milk with an inherently low $\mathrm{Zn}$ content (Butte $e t$ al. 1992; Dorea, 1993) and/or low volume (Brown et al. 1986). To date, studies of the $\mathrm{Zn}$ concentrations of breast milk in poorly nourished lactating women with chronically inadequate $\mathrm{Zn}$ intakes have revealed inconsistent results. In some, breast milk $\mathrm{Zn}$ concentrations have been consistent with those reported for developed countries, and independent of maternal dietary $\mathrm{Zn}$ intakes (Kirsten et al. 1985; Karra et al. 1986; Moser et al. 1988; Simmer et al. 1990); others dispute this finding (Krebs et al. 1985; Shrimpton et al. 1985). 
In many developing countries, breast milk output may also be compromised by the early introduction of weaning foods which replace rather than complement breast milk (Walker, 1990). Very often these weaning foods are prepared as thin porridges from staples with a low energy and nutrient density which fail to make up the nutrient deficit when breast milk no longer meets the infants' needs. If unrefined and unfermented cereals and/or legumes are used, the weaning foods will have a high phytic acid content; consequently $\mathrm{Zn}$ bioavailability will be low. During fermentation, hexa- and penta-inositol phosphates are hydrolysed enzymically to the lower inositol phosphates which do not inhibit $\mathrm{Zn}$ absorption (Lönnerdal et al. 1989). More work is required in developing countries to evaluate the adequacy of dietary $\mathrm{Zn}$ intakes for both exclusively breast fed infants and for weanlings. To date, no recommendations for the $\mathrm{Zn}$ content of weaning foods in developing countries exist (Royal Tropical Institute, Amsterdam, 1987). This is unfortunate because $\mathrm{Zn}$ deficiency impairs appetite, taste acuity, immune and intestinal function during infancy (Hambidge et al. 1972; Krebs et al. 1984; Castillo-Duran et al. 1987; Roy et al. 1992; Schlesinger et al. 1993; Tomkins et al. 1993) as well as growth (Hambidge, 1989). Such functional disturbances will have a further detrimental effect on the growth and development of the infants.

A high proportion of pregnant women from developing countries are probably also at risk through inadequate intakes of $\mathrm{Zn}$. Although no data based on the probability approach are available in the literature, in a Guatemalan study 94 and $25 \%$ of the pregnant women had average $\mathrm{Zn}$ intakes below or less than two-thirds of the US Recommended Dietary Allowance for $\mathrm{Zn}(15 \mathrm{mg})$ respectively, assuming that $20 \%$ of $\mathrm{Zn}$ was absorbed from their diets. Mean $\mathrm{Zn}$ intakes for pregnant rural and urban women in Nigeria were 6.0 and $6.7 \mathrm{mg} / \mathrm{d}$, respectively, whereas during lactation they ranged from 7.3 to $8.2 \mathrm{mg} / \mathrm{d}$ for rural women (Mbofung \& Atinmo, 1987). Corresponding mean intakes for Nepalese (Moser et al. 1988) and Amazonian (Jackson et al. 1988) lactating women were 10.5 and $8.8 \mathrm{mg} \mathrm{Zn/d}$ respectively.

Comparison of $\mathrm{Zn}$ intakes with the current estimated requirements does not take into account the possibility that humans can adapt to chronically low $\mathrm{Zn}$ intakes and achieve $\mathrm{Zn}$ balance by increasing $\mathrm{Zn}$ absorption (King, 1986). Certainly, Amazonian lactating women maintained normal $\mathrm{Zn}$ balance in the presence of low intakes of $\mathrm{Zn}$ (and phytate) (Jackson et al. 1988), although there was evidence of functional impairment because breast milk $\mathrm{Zn}$ and retinol contents were abnormally low. Whether such adaptation also occurs in the presence of very high habitual intakes of phytate seems unlikely. Brune et al. (1989) reported that vegetarians did not adapt to their high phytate diet by increased absorption of ${ }^{59} \mathrm{Fe}$.

Probability estimates for risk of $\mathrm{Zn}$ inadequacy do not identify actual individuals in the population who are deficient, or define the severity of the nutrient inadequacy. Such information can only be obtained when the dietary intake data are combined with laboratory and/or clinical indices of $\mathrm{Zn}$ status. This is especially important in developing countries where the coexistence of many other multifaceted health problems often confounds the diagnosis of $\mathrm{Zn}$ deficiency.

\section{LABORATORY ASSESSMENT OF ZINC STATUS}

\section{BIOCHEMICAL INDICES OF ZINC STATUS}

To date, no single, sensitive and specific index of $\mathrm{Zn}$ status exists (Golden, 1989). Serum/plasma $\mathrm{Zn}$ is the most frequently used index in human studies because it can be easily and accurately measured. Nevertheless, this index has several limitations. It can only be used when the serum samples are not haemolysed or contaminated, and conditions such 
as infection are absent. Erythrocytes have a high $\mathrm{Zn}$ content and in cases of $\mathrm{Zn}$ deficiency red cell fragility is increased (Bettger et al. 1978). Parasitaemia is prevalent in many developing countries, and its presence confounds the interpretation of serum $\mathrm{Zn}$ concentrations; during infection values are spuriously low because $\mathrm{Zn}$ is redistributed from the plasma to other tissues (Aggett, 1991; Filteau \& Tomkins, 1994). Other important confounding factors which must be controlled when collecting blood samples for plasma $\mathrm{Zn}$ analysis include diurnal variation in circulating $\mathrm{Zn}$ level, fasting, meal consumption, the time interval between blood collection and separation of the plasma, and contamination of the blood sample from evacuated tubes with rubber stoppers and non-acid washed glassware (Gibson, 1989; Aggett, 1991; Wallock et al. 1993). In general, low plasma/serum $\mathrm{Zn}$ levels indicate deficiency or a redistribution of $\mathrm{Zn}$, but normal levels do not necessarily preclude deficiency. For instance, in cases of chronic but mild $\mathrm{Zn}$ deficiency states, plasma concentrations are often normal (Gibson et al. 1989 b; Ruz et al. 1991), making diagnosis difficult.

Alternative static biochemical indices of $\mathrm{Zn}$ status which have been investigated include the concentrations in hair, urine, leucocytes, neutrophils, platelets and saliva. Available evidence suggests that low concentrations in hair samples collected during infancy and childhood probably reflect chronic suboptimal $\mathrm{Zn}$ status when the confounding effects of severe protein-energy malnutrition and season are absent (Hambidge et al. 1972; Gibson et al. 1989b; Cavan et al. 1993a; Ferguson et al. 1993b). Clinical features of mild Zn deficiency in childhood, such as impairments in linear growth, appetite and taste acuity, have been associated with hair concentrations of less than $1.07 \mu \mathrm{mol} / \mathrm{g}(70 \mu \mathrm{g} / \mathrm{g})$ (Hambidge et al. 1972; Krebs et al. 1984; Smit Vanderkooy \& Gibson, 1987) in the summer, and less than $1.68 \mu \mathrm{mol} / \mathrm{g}(110 \mu \mathrm{g} / \mathrm{g})$ in the winter (Gibson et al. $1989 \mathrm{~b}$; Cavan et al. $1993 a$ ). In some cases, the low hair concentrations have been related to poorly available dietary $\mathrm{Zn}$ (Smit Vanderkooy \& Gibson, 1987; Ferguson et al. 1988; Gibson et al. 1991 b; Cavan et al. 1993a).

Hair $\mathrm{Zn}$ cannot be used in cases of very severe malnutrition when the rate of growth of the hair shaft is often diminished. In such cases, hair $\mathrm{Zn}$ concentrations may be normal or even high (Erten et al. 1978; Bradfield \& Hambidge, 1980). Standardized procedures must be used for sampling, washing, and analysing the hair samples (Hambidge, 1982). Supplementation trials must be undertaken over one year and all the subjects sampled at the same season of the year to minimize the confounding effects of seasonal variation (Gibson et al. 1989a).

Many investigators have failed to find any positive correlations between the $\mathrm{Zn}$ content of hair and serum/plasma Zn concentrations (Hambidge et al. 1972; Walravens et al. 1983, 1989; Gibson et al. 1989 b). These findings are not unexpected. The $\mathrm{Zn}$ content of the hair shaft reflects the quantity of $\mathrm{Zn}$ available to the hair follicle over an earlier time interval. Positive correlations between hair and plasma $\mathrm{Zn}$ concentrations are only observed in chronic, severe deficiency states, in the absence of confounding factors.

Depletion of body $\mathrm{Zn}$ stores causes a reduction in urinary excretion, often before any detectable changes in serum/plasma Zn concentrations (Baer \& King, 1984). Twenty-four hour urine collections are recommended because diurnal variation in urinary $\mathrm{Zn}$ excretion occurs, although casual urine samples can be used if $\mathrm{Zn}$ :creatinine ratios are determined (Zlotkin \& Casselman, 1988). Several factors can affect urinary $\mathrm{Zn}$ concentrations, however, making interpretation of the results difficult. For example, despite the presence of suboptimal $\mathrm{Zn}$ status in sickle cell anaemia, hyperzincuria occurs. The absence of established interpretive criteria for urinary $\mathrm{Zn}$ levels further limits their use (Gibson, 1989).

The $\mathrm{Zn}$ contents of leucocytes or specific cellular types of leucocytes (e.g. neutrophils) have been used as an index of tissue $\mathrm{Zn}$ status; they are said to reflect soft tissue $\mathrm{Zn}$ (Jones 
et al. 1981) and correlate with retinal dark adaptation. They also have a shorter half-life than erythrocytes and hence should detect changes in $\mathrm{Zn}$ status over a shorter time period. Results, however, have been equivocal (Jones et al. 1981; Meadows et al. 1981; Prasad \& Cossack, 1982; Thompson, 1991; Ruz et al. 1992). Relatively large volumes of blood are required and isolation of the leucocytes and specific cellular types, as well as their subsequent analysis, is lengthy and technically difficult, limiting their use in some countries. For example, Milne et al. (1985) have emphasised that the $\mathrm{Zn}$ content of leucocytes is a function of the type of separation used; contamination with $\mathrm{Zn}$ from the anticoagulant, reagents, density gradient system, and/or from erythrocytes and platelets may occur. Changes in the relative proportions of leucocyte subsets with physiological state (e.g. pregnancy) and haematological disorders must also be taken into account in the interpretation of the results. Finally, comparison of results among different studies is difficult because no consensus exists as to how to express $\mathrm{Zn}$ concentrations in the cell types.

Biochemical functional tests measure changes in the activities of certain enzymes or blood components dependent on $\mathrm{Zn}$. Zinc is a constituent of over 200 metallo-enzymes which vary in their responses to $\mathrm{Zn}$ deficiency depending on the tissue examined, their $\mathrm{Zn}$ affinity, and rate of turnover of the enzyme. Of the $\mathrm{Zn}$ metallo-enzymes, activity of serum alkaline phosphatase has been most widely used to assess $\mathrm{Zn}$ status; its response has been inconsistent. In general, its activity is reduced in severe (Rothbaum et al. 1982) but not in mild (Ruz et al. 1991) $\mathrm{Zn}$ deficiency states. No significant changes in activity have been reported in mild $\mathrm{Zn}$ depletion-repletion studies of adults (Ruz et al. 1991), or in most (Hambidge et al. 1972; Walravens \& Hambidge, 1976; Walravens et al. 1983, 1989; Gibson et al. 1989b; Cavan et al. 1993 b), but not all (Udomkesmalee et al. 1992) of the $\mathrm{Zn}$ supplementation studies in infants and children.

The specificity of alkaline phosphatase as an index of $\mathrm{Zn}$ status is also poor; its activity is influenced by many factors other than $\mathrm{Zn}$ status such as low food intake, type of protein consumed, magnesium or manganese deficiency, season, and in states of increased bone turnover (Chesters \& Will, 1978; Koo et al. 1989). Measurements of alkaline phosphatase activity in neutrophils (Ruz et al. 1991), leucocytes (Schiliro et al. 1987), and red blood cell membranes (Ruz et al. 1992; Cavan et al. 1993 b) have also been investigated as indices of $\mathrm{Zn}$ status; more studies are needed before any definite conclusions can be reached. To date, there is no universally accepted $\mathrm{Zn}$ dependent enzyme which can be used to assess mild $\mathrm{Zn}$ deficiency.

Levels of the $\mathrm{Zn}$ binding protein metallothionein have been investigated in serum, urine, or erythrocytes as indices of $\mathrm{Zn}$ status (Golden, 1989). Levels fall in $\mathrm{Zn}$ deficiency as a result of impaired synthesis. Specificity is poor; levels are also affected by Fe deficiency, diurnal rhythm, and acute infection. Metallothionein is said to be much less responsive to stress and infection in erythrocytes than in plasma (Grider et al. 1990), and hence may provide a useful index of $\mathrm{Zn}$ status.

Serum thymulin has also been assessed as a potential index of $\mathrm{Zn}$ status. Thymulin is a $\mathrm{Zn}$ metallopeptide which controls cell mediated immune function (Prasad et al. 1988); its activity falls in mild $\mathrm{Zn}$ deficiency. Plasma somatomedin-C, a peptide of low molecular weight which is regulated by growth hormone, nutrition, and insulin, is increased in response to increases in $\mathrm{Zn}$ concentration in plasma and tibia of rats. Nevertheless, more work is required to establish the sensitivity, specificity, and validity of erythrocyte metallothionein, serum thymulin and somatomedin- $\mathrm{C}$ as indices of $\mathrm{Zn}$ status. 


\section{PHYSIOLOGICAL FUNCTIONAL INDICES OF ZINC STATUS}

Physiological functions dependent on $\mathrm{Zn}$, such as linear and ponderal growth, taste acuity, and immune competence, can also be used to assess $\mathrm{Zn}$ status. Such tests have greater biological significance than the biochemical tests because they measure the biological impact of $\mathrm{Zn}$ deficiency. Their specificity is low, and hence they must always be used in conjunction with biochemical indices.

Diminished taste acuity is a feature of mild $\mathrm{Zn}$ deficiency. Several methods for testing taste acuity have been used. In studies of Canadian (Gibson et al. 1989 b) and Guatemalan (Cavan et al. 1993a) children, significant inverse relationships between recognition threshold for salt and hair $\mathrm{Zn}$ concentrations have been noted. These results suggest that impaired taste acuity can be used as a physiological functional test of suboptimal $\mathrm{Zn}$ nutriture in some children, provided a biochemical index of $\mathrm{Zn}$ status is also used. The test is not suitable, however, for infants and children less than five years of age.

Some changes in body composition have also been observed after $\mathrm{Zn}$ supplementation in some cases of deficiency in children. Specifically, increases in arm circumference were reported in Gambian children (Bates et al. 1993), whereas in Zn supplemented Jamaican children recovering from severe malnutrition, accretion of lean tissue was greater. The latter was attributed to an increased efficiency of nutrients for tissue synthesis after $\mathrm{Zn}$ supplementation. By contrast, triceps skin folds increased in Guatemalan $\mathrm{Zn}$ supplemented children (Cavan et al. 1993 b), probably due to an increase in energy intake concomitant with improved appetite.

From the discussion above, it is evident that diagnosis of $\mathrm{Zn}$ deficiency is hampered by the lack of a single, specific, and sensitive index of status. A large number of indices have been proposed, but many are fraught with problems that affect their use and interpretation, especially in mild $\mathrm{Zn}$ deficiency states. Hence, it is not surprising that the true magnitude of $\mathrm{Zn}$ deficiency in developing countries is not yet known.

\section{ZINC DEFICIENCY THROUGHOUT THE LIFE CYCLE}

\section{INFANCY AND CHILDHOOD}

Cases of severe $\mathrm{Zn}$ deficiency in infancy and childhood are now rare but mild deficiency in infancy and childhood is not uncommon. Growth failure is the most prominent clinical feature of mild Zn deficiency, although impairments in body composition, taste acuity, appetite, immune function, dark adaptation, and delays in secondary sexual maturation have also been described (Hambidge, 1989). Growth failure is also a characteristic feature of childhood growth patterns in many developing countries, which has until recently been attributed to deficits in energy and/or protein. Inadequate $\mathrm{Zn}$ intakes are likely to be an important contributing factor because diets low in protein tend to be low in $\mathrm{Zn}$ (Golden \& Golden, $1981 \mathrm{~b}$ ), and $\mathrm{Zn}$ has such a critical role in protein synthesis, cell replication, and appetite control.

The first cases of human $\mathrm{Zn}$ deficiency were reported in the Middle East among adolescent male dwarfs in the 1960s (Prasad et al. 1963). The syndrome was characterized by impaired growth and delayed sexual maturation, which were shown to respond to $\mathrm{Zn}$ supplementation in later studies (Ronaghy et al. 1969, 1974).

Since these first reports, nutritional $\mathrm{Zn}$ deficiency has been reported in infants and/or children living in some industrialized (Hambidge et al. 1972; Walravens \& Hambidge, 1976; Arcasoy et al. 1978; Buzina et al. 1980; Walravens et al. 1983, 1989, 1992; Smit Vanderkooy \& Gibson, 1987; Gibson et al. 1989 b), and developing (Golden \& 
Table 3. Double-blind zinc supplementation studies in infants

\begin{tabular}{|c|c|c|c|c|c|}
\hline \multirow{3}{*}{$\begin{array}{l}\text { Country, no. of subjects, age of } \\
\text { subjects, experimental treatment, } \\
\text { reference }\end{array}$} & \multicolumn{4}{|c|}{$\begin{array}{l}\text { Mean plasma zinc levels, } \\
(\mu \mathrm{mol} / \mathrm{l})\end{array}$} & \multirow{3}{*}{$\begin{array}{l}\text { Growth effects and } \\
\text { other responses }\end{array}$} \\
\hline & \multicolumn{2}{|c|}{ Zinc suppl. } & \multicolumn{2}{|c|}{ Control } & \\
\hline & Start & End & Start & End & \\
\hline $\begin{array}{l}\text { USA. } 68 \text { normal healthy full term male } \\
\text { infants at birth studied for } 6 \text { months. } \\
\text { Double-blind study. Formula with } \\
1.8 \mathrm{mg} \mathrm{Zn} / 1 \text { v. } 5.8 \mathrm{mg} \mathrm{Zn} / 1 \text {. Walravens } \\
\text { \& Hambidge, } 1976\end{array}$ & & 11.9 & & $11 \cdot 0$ & $\begin{array}{l}\text { Improved weight and } \\
\text { length in males only. }\end{array}$ \\
\hline $\begin{array}{l}\text { France. } 57 \text { normal healthy infants } 5 \cdot 4 \\
\text { months old studied for } 3 \text { months. } \\
\text { Double-blind placebo ( } 32), 5 \mathrm{mg} \mathrm{Zn/d} \\
\text { (25). Walravens et al. } 1992\end{array}$ & & & & & $\begin{array}{l}\text { Improved weight gain. } \\
\text { Improved length gain in } \\
\text { males only. }\end{array}$ \\
\hline $\begin{array}{l}\text { USA. } 50 \text { failure to thrive, } 8-27 \text { months } \\
\text { old studied for } 6 \text { months. Randomized } \\
\text { double-blind trial pair-matched. } 5.7 \mathrm{mg} \\
\text { Zn/d as syrup (25) and placebo ( } 25) \text {. } \\
\text { Walravens et al. } 1989\end{array}$ & $10 \cdot 7$ & 9.8 & $10 \cdot 7$ & $10 \cdot 4$ & $\begin{array}{l}\text { Improved weight } \\
\text { especially in boys. } \\
\text { Tendency to increased } \\
\text { activity of serum } \\
\text { alkaline phosphatase in } \\
\mathrm{Zn} \text { group. }\end{array}$ \\
\hline $\begin{array}{l}\text { Chile. } 32 \text { marasmic infants, } 7-8 \text { months } \\
\text { old, studied for } 90 \mathrm{~d} \text {. Randomized } \\
\text { double-blind trial. } 2 \mathrm{mg} \mathrm{Zn} / \mathrm{kg} \text { daily as } \\
\text { solution (16). Placebo (16). Castillo- } \\
\text { Duran et al. } 1987\end{array}$ & $14 \cdot 7$ & $15 \cdot 6$ & $16 \cdot 1$ & $15 \cdot 6$ & $\begin{array}{l}\text { Weight for length effect. } \\
\text { Decrease in \% anergic } \\
\text { infants, increase in } \\
\text { serum IgA in } \mathrm{Zn} \text { group. }\end{array}$ \\
\hline $\begin{array}{l}\text { Chile. } 39 \text { severely malnourished infants } \\
\text { studied for } 105 \mathrm{~d} \text {. Double-blind trial } \\
1.9 \mathrm{mg} \mathrm{Zn} / \mathrm{kg} \text { daily in formula (19) } v \text {. } \\
0.35 \mathrm{mg} \mathrm{Zn/kg} \mathrm{daily} \mathrm{in} \mathrm{formula} \mathrm{(20).} \\
\text { Schlesinger et al. } 1992\end{array}$ & $19 \cdot 4$ & $18 \cdot 6$ & $23 \cdot 4$ & 18.0 & $\begin{array}{l}\text { Linear length effect. } \\
\text { Improved immune } \\
\text { function. }\end{array}$ \\
\hline $\begin{array}{l}\text { Bangladesh. } 60 \text { severely malnourished } \\
\text { infants } 5-60 \text { months old for } 3 \text { weeks. } \\
\text { Rice based diet ad lib. and vitamins and } \\
\text { minerals. } 10 \mathrm{mg} \mathrm{Zn} / \mathrm{kg} \text { daily if }<6 \mathrm{~kg} \\
\text { or } 50 \mathrm{mg} \mathrm{Zn} / \mathrm{d} \text { for those }>6 \mathrm{~kg} \text { as } \\
\mathrm{ZnSO}_{4} . \text { Non-supplemented group (30). } \\
\text { Khanum } \text { et al. } 1988\end{array}$ & $8 \cdot 2$ & $18 \cdot 5$ & 7.9 & 10.6 & $\begin{array}{l}\text { Improved weight gain } \\
\text { and weight for length. }\end{array}$ \\
\hline $\begin{array}{l}\text { Bangladesh. } 65 \text { children with AD 3-24 } \\
\text { months old. } 152 \text { with PD 3-24 months } \\
\text { old supplemented for } 2 \text { weeks. Followed } \\
\text { for } 2 \text { and } 3 \text { months in a double-blind } \\
\text { randomized study (placebo } v .15 \mathrm{mg} \\
\mathrm{Zn} / \mathrm{kg} \text { daily). Roy et al. } 1993\end{array}$ & & & & & $\begin{array}{l}\text { Improved length gain in } \\
\text { AD group, and in PD } \\
\text { with }<90 \% \text { weight } / \text { age } \\
\text { and }<90 \% \text { height/age. } \\
\text { Reduced no. of episodes } \\
\text { of diarrhoea in AD and } \\
\text { PD groups and attack } \\
\text { rate of respiratory tract } \\
\text { infections in AD group } \\
\text { only. }\end{array}$ \\
\hline $\begin{array}{l}\text { Chile. } 80 \text { SGA neonates } 38-41 \text { weeks ges- } \\
\text { tational age studied from birth for } 6 \\
\text { months. Double-blind randomized study } \\
\text { with placebo (41), } 3 \mathrm{mg} \mathrm{Zn} / \mathrm{d} \text { (39). Rod- } \\
\text { riguez et al. } 1991\end{array}$ & $12 \cdot 6$ & 10.5 & $12 \cdot 1$ & 8.9 & $\begin{array}{l}\text { Improved linear growth } \\
\text { and weight gain. No } \\
\text { difference in head } \\
\text { circumference. }\end{array}$ \\
\hline
\end{tabular}

$\mathrm{AD}$, acute diarrhoea; $\mathrm{PD}$, persistent diarrhoea; SGA, small for gestational age. 


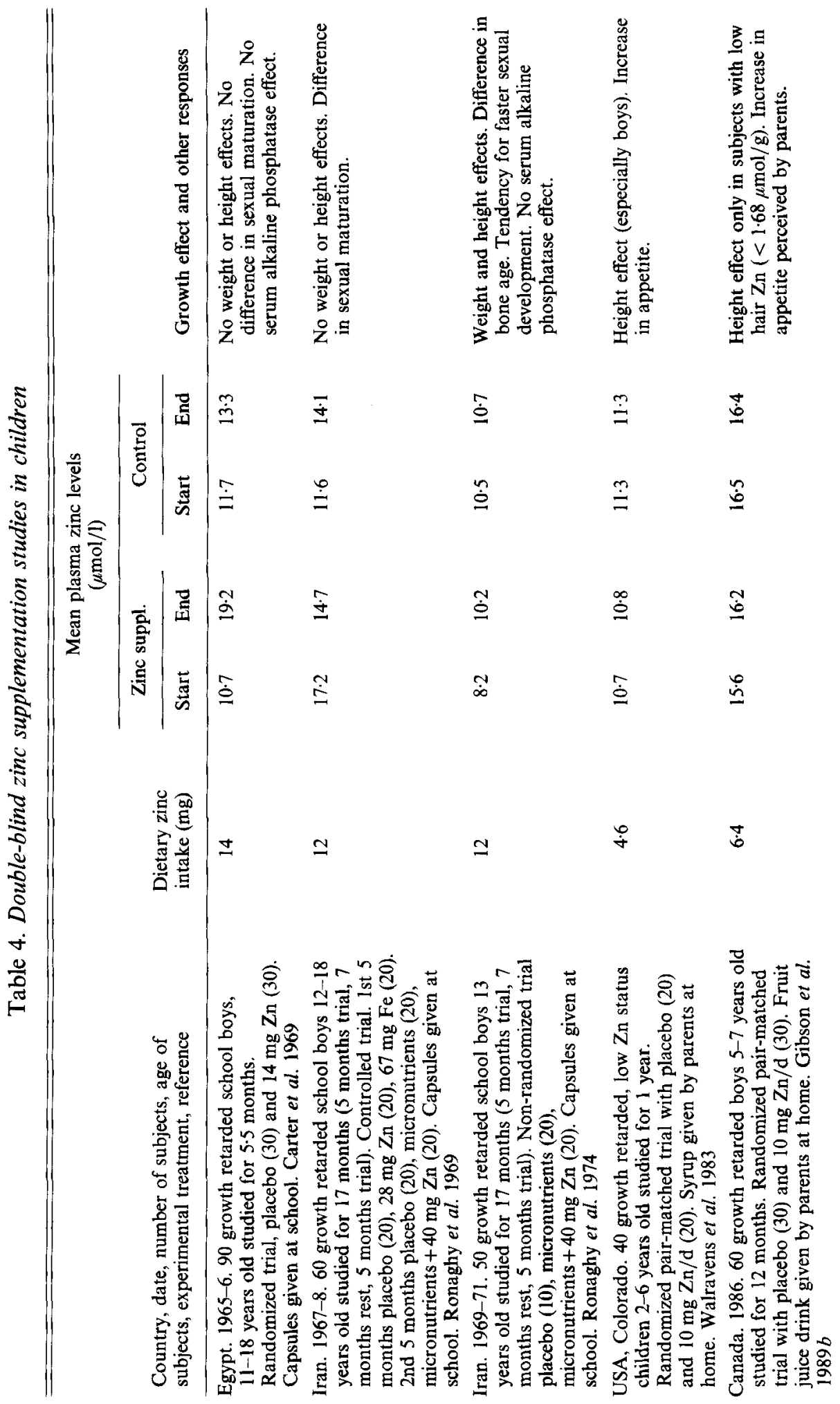




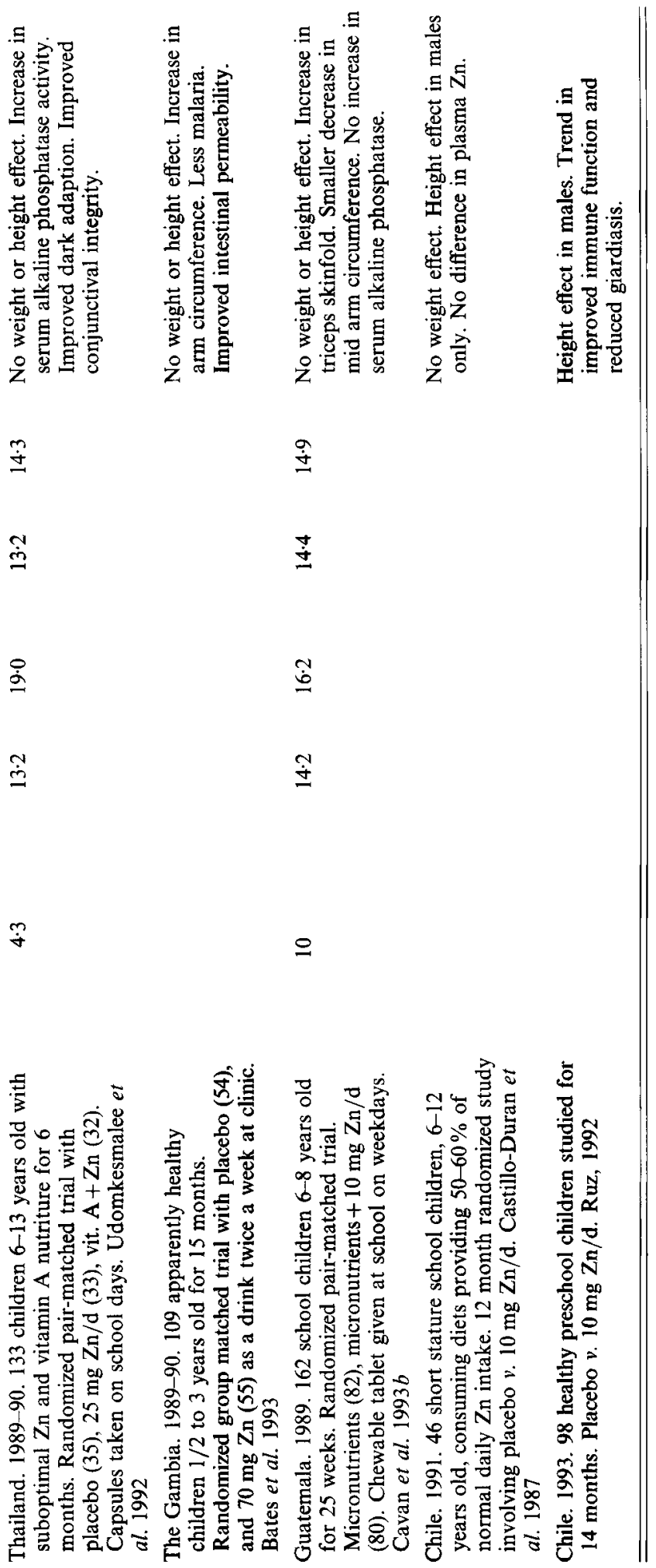


Golden, 1981 a; Xue-Cun et al. 1985; Castillo-Duran et al. 1987; Khanum et al. 1988; Simmer et al. 1988; Udomkesmalee et al. 1990, 1992; Schlesinger et al. 1992; Bates et al. 1993; Cavan et al. 1993 a, b; Roy et al. 1993; M. Ruz, 1993, pers. comm.; Smith et al. 1993) countries (Tables $3 \& 4$ ). In most of these studies, clinical signs of severe $\mathrm{Zn}$ deficiency were not apparent. Instead, mild $\mathrm{Zn}$ deficiency existed, characterized by reductions in linear and/or ponderal growth, and/or impairments in taste acuity, appetite, immune and intestinal function, and dark adaptation, some of which have responded positively to $\mathrm{Zn}$ supplementation in double-blind studies. Biochemical evidence of $\mathrm{Zn}$ deficiency has not been a consistent finding. This is not unexpected; physiological functional consequences (e.g. growth retardation) of mild $\mathrm{Zn}$ deficiency are often apparent before the $\mathrm{Zn}$ concentrations in plasma and/or tissues are significantly reduced (Gibson et al. 1989 b; Ruz et al. 1991), emphasizing the importance of confirming mild $\mathrm{Zn}$ deficiency by a positive response to a supplement in double-blind studies.

\section{PREGNANCY}

Animal studies have clearly demonstrated the teratogenic effects of $\mathrm{Zn}$ deficiency (Hurley \& Swenerton, 1966), but results of human studies have been inconsistent. In severe $\mathrm{Zn}$ deficiency in humans arising from acrodermatitis enteropathica, abortions and gross congenital malformations (e.g. anencephaly) have been reported (Hambidge et al. 1975). The existence of mild $\mathrm{Zn}$ deficiency during pregnancy and its effect on pregnancy outcome is less clear, in part because of difficulties in establishing the existence of marginal $\mathrm{Zn}$ status during pregnancy and/or inadequacies in the experimental designs. No double-blind $\mathrm{Zn}$ supplementation studies during pregnancy have been carried out in developing countries.

Serum $\mathrm{Zn}$ has been the most frequently used index of $\mathrm{Zn}$ status during pregnancy; it declines during pregnancy even in the presence of optimal maternal $\mathrm{Zn}$ nutriture (Swanson \& King, 1987), attributed in part to expansion in plasma volume. Nevertheless, in women with inadequate $\mathrm{Zn}$ intakes, the decline in serum $\mathrm{Zn}$ during pregnancy may be abnormally large (Hambidge et al. 1983; Cherry et al. 1989).

Relationships between maternal plasma $\mathrm{Zn}$ and pregnancy outcome have been inconsistent, and have varied with both the stage of gestation and the outcome variable measured (Swanson \& King, 1987). For example, plasma $\mathrm{Zn}$ correlated weakly with birth weight when sampled at mid pregnancy (McMichael et al. 1982), more strongly in early rather than in later pregnancy, i.e. third trimester (Neggers et al. 1990), or not at all (Arcasoy et al. 1978; Buzina et al. 1980; Hambidge et al. 1983; Campbell-Brown et al. 1985; Hunt et al. 1985; Tuttle et al. 1985; Mahomed et al. 1989). Plasma $\mathrm{Zn}$ has also been reported to correlate with pregnancy complications such as prolonged labour, hypertension, postpartum haemorrhage, spontaneous abortions, and/or congenital malformations by some (Jameson, 1976; Çavdar et al. 1980, 1991; Cherry et al. 1981; McMichael et al. 1982; Soltan \& Jenkins, 1982; Hunt et al. 1985) but not all (Breskin et al. 1983; Mukherjee et al. 1984) investigators. In some double-blind Zn supplementation studies, significant reductions in pregnancy complications have been observed in the $\mathrm{Zn}$ treated compared to the placebo group (Hunt et al. 1984; Cherry et al. 1989; Jameson et al. 1990; Simmer et al. 1991) (Table 5), associated in some cases with alterations in prostaglandin metabolism (O'Dell et al. 1977).

Some relationships have also been reported between low maternal $\mathrm{Zn}$ concentrations in leucocytes and/or lymphocytes and intrauterine growth retardation (Meadows et al. 1981; Simmer \& Thompson, 1985), low birth weight (Wells et al. 1987; Malhotra et al. 1990), and neural tube defects (Hinks et al. 1989). In two double-blind $\mathrm{Zn}$ supplementation studies 
Table 5. Zinc supplementation studies in pregnant women

\begin{tabular}{|c|c|c|}
\hline $\begin{array}{l}\text { Country, date, no. of subjects, type of subjects, } \\
\text { experimental treatment, reference }\end{array}$ & $\begin{array}{l}\text { Dietary zinc } \\
\text { intake }(\mathrm{mg})\end{array}$ & Responses \\
\hline $\begin{array}{l}\text { UK. } 1985-6.494 \text { middle class women studied for } \\
\text { last } 4 \text { months of pregnancy. Randomized double- } \\
\text { blind trial with placebo ( } 248 \text { ) and } 20 \mathrm{mg} \mathrm{Zn} / \mathrm{d} \\
\text { (246). Capsules taken at home. Mahomed et al. } \\
1989\end{array}$ & 9 & $\begin{array}{l}\text { No effect on birth weight. No } \\
\text { difference in leucocyte } \mathrm{Zn} \text { in } \\
\text { supplemented and placebo group. }\end{array}$ \\
\hline $\begin{array}{l}\text { USA, New Orleans. } 556 \text { low income adolescent } \\
\text { women studied for last } 3 \text { months of pregnancy. } \\
\text { Randomized double-blind trial with placebo (288) } \\
\text { and } 30 \mathrm{mg} \mathrm{Zn} / \mathrm{d}(268) \text {. Tablets taken at home. } \\
\text { Cherry et al. } 1989\end{array}$ & $?$ & $\begin{array}{l}\text { No effect on birth weight. Reduced } \\
\text { rates of prematurity and neonatal } \\
\text { morbidity. }\end{array}$ \\
\hline $\begin{array}{l}\text { USA, Los Angeles. } 1981-2.138 \text { Hispanic teenagers } \\
\text { studied for last } 4 \text { months of pregnancy. Randomiz- } \\
\text { ed double-blind trial with micronutrients (68) and } \\
\text { micronutrients }+20 \mathrm{mg} \mathrm{Zn} / \mathrm{d}(70) \text {. Capsules taken } \\
\text { at home. Hunt et al. } 1985\end{array}$ & $9 \cdot 8$ & No effect on birth weight. \\
\hline $\begin{array}{l}\text { USA, Los Angeles. } 213 \text { Hispanic low income } \\
\text { women enrolled }<27 \text { week gestation age. } \\
\text { Randomized double-blind trial with micronutrients } \\
\text { (106) and micronutrients }+20 \mathrm{mg} \mathrm{Zn} / \mathrm{d}(107) \text {. } \\
\text { Hunt et al. } 1984\end{array}$ & $9 \cdot 3$ & $\begin{array}{l}\text { No effect on birth weight. Reduced } \\
\text { incidence of pregnancy induced } \\
\text { hypertension. }\end{array}$ \\
\hline $\begin{array}{l}\text { UK. } 56 \text { pregnant females at risk of SGA infants. } \\
\text { Studied last } 15-25 \text { weeks. Randomized double- } \\
\text { blind trial with placebo (26) and } 22.5 \mathrm{mg} \mathrm{Zn/d} \\
\text { (30). Simmer et al. } 1991\end{array}$ & $?$ & $\begin{array}{l}\text { Lower incidence of IUGR. Labour } \\
\text { induced less often. C-section less } \\
\text { often. }\end{array}$ \\
\hline $\begin{array}{l}\text { USA. } 46 \text { pregnant middle income females studied } \\
\text { for } 7-9 \text { months. Not randomized double-blind } \\
\text { study. Placebo (36) v. } 15 \mathrm{mg} \mathrm{Zn} / \mathrm{d}(10) \text {. Tablet } \\
\text { taken } 2 \mathrm{~h} \text { after dinner. Hambidge et al. } 1983\end{array}$ & 11 & $\begin{array}{l}\text { No effect on birth weight. No other } \\
\text { effects observed. }\end{array}$ \\
\hline $\begin{array}{l}\text { Sweden. } 1983-6.1231 \text { pregnant women. Not } \\
\text { randomized double-blind study. } 15-90 \mathrm{mg} \mathrm{Zn} / \mathrm{d} \\
\text { (depending on serum } \mathrm{Zn} \text { ) given to } 598 \text { subjects; } \\
633 \text { given no } \mathrm{Zn} \text { supplement. Jameson et al. } 1990\end{array}$ & $9 \cdot 4$ & $\begin{array}{l}\text { Fewer preterm deliveries before } 33 \text { rd } \\
\text { week of gestation. Reduction in } \\
\text { perinatal deaths; fewer spontaneous } \\
\text { abortions. }\end{array}$ \\
\hline
\end{tabular}

C-section, Caesarian section; IUGR, intra-uterine growth retardation; SGA, small for gestational age.

(Mahomed et al. 1989; Thauvin et al. 1992), however, no differences in leucocyte $\mathrm{Zn}$ concentrations between the two groups were observed.

Several adaptive mechanisms exist during pregnancy to help meet the increased demands for $\mathrm{Zn}$, including an increase in absorption, a reduction in endogenous losses, redistribution of tissue Zn, and an efficient maternal-fetal transfer (Swanson \& King, 1987). Although such adaptive mechanisms may be adequate to prevent $\mathrm{Zn}$ deficiency in women in developed countries, they may not be sufficient for pregnant women from developing countries, whose $\mathrm{Zn}$ status may be especially low because of frequent reproductive cycling, excessive losses of endogenous $\mathrm{Zn}$, combined with diets low in readily available $\mathrm{Zn}$. Unfortunately, however, investigations of the $\mathrm{Zn}$ status of pregnant women in developing countries are limited (Çavdar et al. 1980; Prema, 1980; Okonofua et al. 1989, 1990); none has involved double-blind $\mathrm{Zn}$ supplementation trials.

In view of the inconsistencies noted above, the precise nature of the association between $\mathrm{Zn}$ status and pregnancy outcome remains unclear. Existing evidence suggests that the prevalence of deficiency in women during pregnancy in developing countries is likely to be 
Table 6. Double-blind zinc supplementation studies in lactating women

\begin{tabular}{|c|c|c|}
\hline $\begin{array}{l}\text { Country, no. of subjects, type of subjects, } \\
\text { experimental treatment, reference }\end{array}$ & $\begin{array}{l}\text { Dietary zinc } \\
\text { intake }(\mathrm{mg})\end{array}$ & Response \\
\hline $\begin{array}{l}\text { Brazil, Amazon region. } 65 \text { poor urban women } \\
\text { studied for first } 5 \text { months of lactation. } \\
\text { Randomized trial with placebo ( } 28) \text { and group } \\
\text { consuming } 15 \mathrm{mg} \mathrm{Zn} / \mathrm{d}(37) \text {. Capsules taken at } \\
\text { home. Shrimpton et al. } 1983 \text { and Shrimpton et al. } \\
1985\end{array}$ & 23 & $\begin{array}{l}\text { No effect on milk } \mathrm{Zn} \text { levels. Milk } \\
\text { vitamin A levels increased. Less } \\
\text { diarrhoea in infants. }\end{array}$ \\
\hline $\begin{array}{l}\text { USA, Colorado. } 53 \text { middle income lactating } \\
\text { women, for varying durations up to } 9 \text { months. } \\
\text { Controlled (8) trial with placebo ( } 39 \text { ) and group } \\
\text { consuming } 15 \mathrm{mg} \mathrm{Zn} / \mathrm{d}(14) \text {. Tablets taken at } \\
\text { home. Krebs et al. } 1985\end{array}$ & $12 \cdot 2$ & Decreased fall in milk $\mathrm{Zn}$ levels. \\
\hline $\begin{array}{l}\text { USA, Indiana. } 49 \text { middle income mothers studied } \\
\text { during first } 6 \text { months of lactation. Controlled trial } \\
\text { with groups consuming micronutrients }(25) \text { and } \\
\text { micronutrients }+25 \mathrm{mg} \mathrm{Zn}(24) \text {. Different } \\
\text { commercial supplements taken at home. Karra et } \\
\text { al. } 1986\end{array}$ & $11 \cdot 2$ & Higher milk $\mathrm{Zn}$ levels. \\
\hline $\begin{array}{l}\text { USA, Maryland. } 40 \text { middle income women studied } \\
\text { during the first } 6 \text { months of lactation. Randomized } \\
\text { double-blind trial with groups consuming } \\
\text { micronutrients }(20) \text { and micronutrients }+25 \mathrm{mg} \\
\text { Zn/d (20). Tablets taken at home. Moser-Veillon } \\
\text { \& Reynolds, } 1990\end{array}$ & 12 & No effect on milk $\mathrm{Zn}$ levels. \\
\hline
\end{tabular}

higher than that in developed countries, but large, well designed, double-blind $\mathrm{Zn}$ supplementation trials are required to confirm the existence of nutritional deficiency and its precise impact on pregnancy outcome.

\section{LACTATION}

Studies of maternal $\mathrm{Zn}$ status during lactation are limited (Table 6). Some have documented low plasma concentrations in the presence of normal concentrations in hair, urine (Jackson et al. 1988), and/or breast milk, even in poorly nourished lactating women with chronically inadequate intakes of dietary $\mathrm{Zn}$ (Kirsten et al. 1985; Karra et al. 1986; Simmer et al. 1990). Two $\mathrm{Zn}$ supplementation studies during lactation (Krebs et al. 1985; Shrimpton et al. 1985) documented a reduction in the abnormally steep decline in breast milk $\mathrm{Zn}$ content during late lactation, although the numbers of subjects in these studies were small. Furthermore, the incidence of diarrhoea in the infants decreased, and milk retinol content was maintained at a higher level throughout lactation in the $\mathbf{Z n}$ supplemented Amazonian women (Shrimpton et al. 1983, 1985).

By contrast, in a US study in Indiana (Karra et al. 1986) in which $25 \mathrm{mg} \mathrm{Zn/d}$ were given, $\mathrm{Zn}$ levels of breast milk apparently increased. Such increases were not observed by MoserVeillon \& Reynolds (1990), despite a comparable daily Zn supplement to US Maryland lactating women. The study of Karra et al. (1986), unlike the Maryland study (MoserVeillon \& Reynolds, 1990), was not a double-blind randomized trial.

Even in malnourished women from developing countries whose breast milk $\mathbf{Z n}$ concentrations are not compromised, their volume of breast milk may be reduced (Brown 
et al. 1986), thus contributing to growth failure in early infancy. Traditional weaning foods used in many developing countries are often based on unrefined cereals and/or legumes, low in bioavailable $\mathrm{Zn}$. If these weaning foods are not processed to reduce their phytic acid content, their use may further compromise infant growth, especially if they replace rather than complement breast milk (Walker, 1990). Strategies which can be used in developing countries to reduce the phytic acid content of traditional staple foods, including weaning foods, are outlined below.

\section{NUTRITION INTERVENTION STRATEGIES TO PREVENT ZINC DEFICIENCY IN DEVELOPING COUNTRIES}

Both short term and long term nutrition intervention strategies can be used to prevent $\mathrm{Zn}$ deficiency in developing countries: (1) supplementation; (2) fortification; and (3) dietary modification/diversification using traditional household techniques. For pregnant women, supplementation or fortification is appropriate because a relatively short term response is required to improve their $\mathrm{Zn}$ status before the end of pregnancy. Moreover, requirements for $\mathrm{Zn}$ during pregnancy, like $\mathrm{Fe}$, cannot be met from dietary sources alone. Such approaches can also be used to provide several micronutrients simultaneously. They do, however, rely on a stable infrastructure and require financial support on a long standing economic basis if they are to be successful. All too often such programmes have been suspended for economic, political, and logistical reasons.

The third approach, dietary modification/diversification, involves changes in food selection patterns and/or traditional household methods for preparing and processing indigenous foods. It is a more economically feasible, culturally acceptable, and sustainable intervention for alleviating $\mathrm{Zn}$ deficiency in developing countries. Possible dietary changes to improve both the content and bioavailability of $\mathrm{Zn}$ include increasing the consumption of flesh foods, rich sources of readily available $\mathrm{Zn}$, when economically feasible, and making modifications to food preparation and processing practices to reduce the level of the higher inositol phosphates in plant based staples. Higher inositol phosphates can be hydrolysed to lower inositol phosphates enzymically via fermentation and/or germination (Svanberg \& Sandberg, 1988). Alternatively, in some cases non-enzymic hydrolysis of the higher inositol phosphates can be achieved by thermal processing, or soaking, provided the phytic acid is present as the soluble potassium salt (Reddy et al. 1989). The extent of the hydrolysis of the higher inositol phosphates can be monitored using the HPLC method for phytic acid analysis (Lehrfeld, 1989). The latter, unlike the AOAC method (Harland \& Oberleas, 1986), differentiates the hexaphosphate and pentaphosphate from the lower inositol phosphates. Only the former inhibit the bioavailability of $\mathrm{Zn}$ (Tao et al. 1986; Lönnerdal et al. 1989).

To be successful, these dietary modifications/diversifications must be introduced using well designed educational and social marketing projects aimed to change attitudes and dietary behaviours. To enhance their effectiveness and sustainability, they should be integrated into ongoing national health and nutrition programmes in developing countries which emphasize the broader health consequences of micronutrient deficiencies. This approach has been highly successful in the Philippines for controlling vitamin A deficiency (Solon, 1986). Implementation of these dietary strategies could have far reaching consequences for both maternal and infant health in many developing countries, decreasing morbidity and complications in pregnancy, reducing mortality during childbirth, risk of prematurity and low birth weight, and enhancing growth and development in infancy and childhood. 


\section{REFERENCES}

Aggett, P. J. (1991). The assessment of zinc status: a personal view. Proceedings of the Nutrition Society 50, 9-17. Arcasoy, A., Çavdar, A. O. \& Babacan, E. (1978). Decreased iron and zinc absorption in Turkish children with iron deficiency and geophagia. Acta Hematologica 60, 76-84.

Baer, M. T. \& King, J. C. (1984). Tissue zinc levels and zinc excretion during experimental zinc depletion in young men. American Journal of Clinical Nutrition 39, 556-570.

Bates, C. J., Evans, P. H., Dardenne, M., Prentice, A., Lunn, P. G., Northrop-Clewes, C. A., Hoare, S., Cole, T. J., Horan, S. J., Longman, S. C., Stirling, D. \& Aggett, P. J. (1993). A trial of zinc supplementation in young rural Gambian children. British Journal of Nutrition 69, 243-255.

Beaton, G. H. (1985). Uses and limits of the use of the Recommended Dietary Allowances for evaluating dietary intake data. American Journal of Clinical Nutrition 41, 155-164.

Bettger, W. J., Fish, T. J. \& O'Dell, B. L. (1978). Effects of copper and zinc status of rats on erythrocyte stability and superoxide dismutase activity. Proceedings of the Society for Experimental Biology and Medicine 158, 279-282.

Bindra, G. S., Gibson, R. S. \& Thompson, L. U. (1986). [Phytate][calcium]/[zinc] ratios in Asian immigrant lactoovo vegetarian diets and their relationship to zinc nutriture. Nutrition Research 6, 475-483.

Bradfield, R. B. \& Hambidge, K. M. (1980). Problems with hair zinc as an indicator of body zinc status. Lancet i, 363.

Breskin, M. W., Worthington-Roberts, B. S., Knopp, R. H., Brown, Z., Plovie, B., Mottet, N. K. \& Mills, J. L. (1983). First trimester serum zinc concentrations in human pregnancy. American Journal of Clinical Nutrition 38, 943-953.

Brown, K., Akhtar, N. A., Robertson, A. D. \& Ahmed, M. G. (1986). Lactational capacity of marginally nourished mothers: relationships between maternal nutritional status and quantity and proximate composition of milk. Pediatrics 78, 909 -919.

Brune, M., Rossander, L. \& Hallberg, L. (1989). Iron absorption: no intestinal adaptation to a high-phytate diet. American Journal of Clinical Nutrition 49, 542-545.

Butte, N. F., Villalpando, S., Wong, W. W., Flores-Huerta, S., Hernandez-Beltran, M. de J., O'Brian Smith, E. $\&$ Garza, C. (1992). Human milk intake and growth faltering of rural Mesoamerindian infants. American Journal of Clinical Nutrition 55, 1109-1116.

Butterworth, C. E., Hatch, K., Cole, P., Sauberlich, H. E., Tamura, T., Cornwell, P. E. \& Soong, S.-J. (1988). Zinc concentration in plasma and erythrocytes of subjects receiving folic acid supplementation. American Journal of Clinical Nutrition 47, 484-486.

Buzina, R., Jušić, M., Sapunar, J. \& Milanović, N. (1980). Zinc nutrition and taste acuity in school children with impaired growth. American Journal of Clinical Nutrition 33, 2262-2267.

Campbell-Brown, M., Ward, R. J., Haines, A. P., North, W. R. S., Abraham, R. \& McFadyen, I. R. (1985). Zinc and copper in Asian pregnancies - is there evidence for a nutritional deficiency? British Journal of Obstetrics and Gynaecology 92, 875-885.

Carter, J. P., Grivetti, L. E., Davis, J. T., Nasiff, S., Mansour, A., Mousa, W. A., Atta, A., Patwardhan, V. N., Moneim, M. A., Abdou, I. A. \& Darby, W. J. (1969). Growth and sexual development of adolescent Egyptian village boys. Effects of zinc, iron, and placebo supplementation. American Journal of Clinical Nutrition 22 , 59-78.

Casey, C. E., Neville, M. C. \& Hambidge, K. M. (1989). Studies in human lactation: secretion of zinc, copper, and manganese in human milk. American Journal of Clinical Nutrition 49, 773-785.

Castillo-Duran, C., Heresi, G., Fisberg, M. \& Uauy, R. (1987). Controlled trial of zinc supplementation during recovery from malnutrition: effects on growth and immune function. American Journal of Clinical Nutrition $\mathbf{4 5}$, $602-608$.

Cavan, K. R., Gibson, R. S., Grazioso, C. F., Isalgue, A. M., Ruz, M. \& Solomons, N. W. (1993a). Growth and body composition of periurban Guatemalan children in relation to zinc status: a cross-sectional study. American Journal of Clinical Nutrition 57, 334-343.

Cavan, K. R., Gibson, R. S., Grazioso, C. F., Isalgue, A. M., Ruz, M. \& Solomons, N. W. (1993b). Growth and body composition of periurban Guatemalan children in relation to zinc status: a zinc intervention trial. American Journal of Clinical Nutrition 57, 344-352.

Çavdar, A. O., Babacan, E. \& Arcasoy, A. (1980). Effect of nutrition on serum zinc concentration during pregnancy in Turkish women. American Journal of Clinical Nutrition 33, 542-544.

Çavdar, A. O., Bahceci, M., Akar, N., Erten, J. \& Yavuz, H. (1991). Effect of zinc supplementation in a Turkish woman with two previous anencephalic infants. Gynecologic and Obstetric Investigation 32, 123-125.

Cherry, F. F., Bennett, E. A., Bazzano, G. S., Johnson, L. K., Fosmire, G. J. \& Batson, H. K. (1981). Plasma zinc in hypertension/toxemia and other reproductive variables in adolescent pregnancy. American Journal of Clinical Nutrition 34, 2367-2375.

Cherry, F. F., Sandstead, H. H., Rojas, P., Johnson, L. K., Batson, H. K. \& Wang, X. B. (1989). Adolescent pregnancy: associations among body weight, zinc nutriture, and pregnancy outcome. American Journal of Clinical Nutrition 50, 945-954.

Chesters, J. K. \& Will, M. (1978). The assessment of zinc status of an animal from the uptake of ${ }^{65} \mathrm{Zn}$ by the cells of whole blood in vitro. British Journal of Nutrition 38, 297-306. 
Cossack, Z. T. \& Prasad, A. S. (1983). Effect of protein source on the bioavailability of zinc in human subjects. Nutrition Research 3, 23-31.

Davies, N. T., Carswell, A. J. P. \& Mills, C. F. (1985). The effect of variations in dietary calcium intake on the phytate-zinc interaction in rats. In Trace Elements in Man and Animals (5th International Symposium), pp. 456-457 [C. F. Mills, I. Bremner and J. K. Chesters, editors]. Farnham Royal: Commonwealth Agricultural Bureaux.

Dorea, J. G. (1993). Is zinc a first limiting nutrient in human milk? Nutrition Research 13, 659-666.

Erten, J., Arcasoy, A., Cavdar, A. O. \& Cin, S. (1978). Hair zinc levels in healthy and malnourished children. American Journal of Clinical Nutrition 31, 1172-1174.

Ferguson, E. L. (1992). A comparison of food consumption patterns and zinc status of preschool children from Southern Malawi and Ghana. Ph.D. thesis, University of Guelph.

Ferguson, E. L., Gibson, R. S., Opare-Obisaw, C., Osei-Opare, F., Stephen, A. M., Lehrfeld, J. \& Thompson, L. U. (1993 $a$ ). The zinc, calcium, copper, manganese, nonstarch polysaccharide and phytate content of seventyeight locally grown and prepared African foods. Journal of Food Composition and Analysis 6, 87-99.

Ferguson, E. L., Gibson, R. S., Opare-Obisaw, C., Ounpuu, S., Thompson, L. U. \& Lehrfeld, J. (1993b). The zinc nutriture of preschool children living in two African countries. Journal of Nutrition 123, 1487-1496.

Ferguson, E. L., Gibson, R. S., Thompson, L. U. \& Ounpuu, S. (1989a). Dietary calcium, phytate, and zinc intakes and the calcium, phytate, and zinc molar ratios of the diets of a selected group of East African children. American Journal of Clinical Nutrition 50, 1450-1456.

Ferguson, E. L., Gibson, R. S., Thompson, L. U., Ounpuu, S. \& Berry, M. (1988). Phytate, zinc, and calcium contents of 30 East African foods and their calculated phytate: $\mathrm{Zn}, \mathrm{Ca}$ :phytate, and [Ca][phytate]/[Zn] molar ratios. Journal of Food Composition and Analysis 1, 316-325.

Ferguson, E. L., Gibson, R. S., Weaver, S. D., Heywood, P., Heywood, A. \& Yaman, C. (1989b). The mineral content of commonly consumed Malawian and Papua New Guinean foods. Journal of Food Composition and Analysis 2, 260-272.

Filteau, S. M. \& Tomkins, A. M. (1994). Micronutrients and tropical infections. Transactions of the Royal Society of Tropical Medicine and Hygiene 88, 1-3.

Fitzgerald, S. L., Gibson, R. S., Quan de Serrano, J., Portocarrero, L., Vasquez, A., de Zepeda, E., LopezPalacios, C. Y., Thompson, L. U., Stephen, A. M. \& Solomons, N. W. (1993). Trace element intakes and dietary phytate $/ \mathrm{Zn}$ and $\mathrm{Ca} \times$ phytate $/ \mathrm{Zn}$ millimolar ratios of periurban Guatemalan women during the third trimester of pregnancy. American Journal of Clinical Nutrition 57, 195-201.

Fordyce, E. J., Forbes, R. M., Robins, K. R. \& Erdman, J. W. (1987). Phytate x calcium/zinc molar ratios: are they predictive of zinc bioavailability? Journal of Food Science 52, 440-444.

Gibson, R. S. (1989). Assessment of trace element status in humans. Progress in Food and Nutrition Science 13, 67-111.

Gibson, R. S., Ferguson, E. F., Smit Vanderkooy, P. D. \& MacDonald, A. C. (1989a). Seasonal variations in hair zinc concentrations in Canadian and African children. Science of the Total Environment 84, 291-298.

Gibson, R. S., Heywood, A., Yaman, C., Sohlström, A., Thompson, L. U. \& Heywood, P. (1991 a). Growth in children from the Wosera subdistrict, Papua New Guinea, in relation to energy and protein intakes and zinc status. American Journal of Clinical Nutrition 53, 782-789.

Gibson, R. S., Smit Vanderkooy, P. D., MacDonald, A. C., Goldman, A., Ryan, B. A. \& Berry, M. (1989b). A growth-limiting, mild zinc-deficiency syndrome in some Southern Ontario boys with low height percentiles. American Journal of Clinical Nutrition 49, 1266-1273.

Gibson, R. S., Smit Vanderkooy, P. D. \& Thompson, L. U. (1991 b). Dietary phytate $\times$ calcium/zinc millimolar ratios and zinc nutriture in some Ontario preschool children. Biological Trace Element Research 30, 87-94.

Giugliano, R. \& Millward, D. J. (1984). Growth and zinc homeostasis in the severely Zn-deficient rat. British Journal of Nutrition 52, 545-560.

Golden, M. H. N. (1989). The diagnosis of zinc deficiency. In Zinc in Human Biology (International Life Sciences Institute of Human Nutrition Reviews), pp. 324-333 [C. F. Mills, editor]. Berlin: Springer-Verlag.

Golden, M. H. N. \& Golden, B. E. (1981 a). Effect of zinc supplementation on the dietary intake, rate of weight gain, and energy cost of tissue deposition in children recovering from severe malnutrition. American Journal of Clinical Nutrition 34, 900-908.

Golden, M. H. N. \& Golden, B. E. $(1981 b)$. Trace elements: potential importance in human nutrition with particular reference to zinc and vanadium. British Medical Bulletin 37, 31-36.

Grider, A., Bailey, L. B. \& Cousins, R. J. (1990). Erythrocyte metallothionein as an index of zinc status in humans. Proceedings of the National Academy of Sciences, USA 87, 1259-1262.

Hambidge, K. M. (1982). Hair analyses: worthless for vitamins, limited for minerals. American Journal of Clinical Nutrition 36, 943-949.

Hambidge, K. M. (1989). Mild zinc deficiency in children. In Zinc in Human Biology (International Life Sciences Institute of Human Nutrition Reviews), pp. 285-295 [C. F. Mills, editor]. Berlin: Springer-Verlag.

Hambidge, K. M., Hambidge, C., Jacobs, M. \& Baum, J. D. (1972). Low levels of zinc in hair, anorexia, poor growth, and hypogeusia in children. Pediatric Research 6, 868-874.

Hambidge, K. M., Krebs, N. F., Jacobs, M. A., Favier, A., Guyette, L. \& Ikle, D. N. (1983). Zinc nutritional status during pregnancy: a longitudinal study. American Journal of Clinical Nutrition 37, 429-442. 
Hambidge, K. M., Neldner, K. H. \& Walravens, P. A. (1975). Zinc, acrodermatitis enteropathica, and congenital malformations. Lancet i, 577-578.

Harland, B. F. \& Oberleas, D. (1986). Anion-exchange method for determination of phytate in foods: collaborative study. Journal of the Association of Official Analytical Chemists 69, 667-670.

Harland, B. F. \& Peterson, M. (1978). Nutritional status of lacto-ovo vegetarian Trappist monks. Journal of the American Dietetic Association 72, 259-264.

Hinks, L. J., Ogilvy-Stuart, A., Hambidge, K. M. \& Walker, V. (1989). Maternal zinc and selenium status in pregnancies with a neural tube defect or elevated plasma $\alpha$-fetoprotein. British Journal of Obstetrics and Gynaecology 96, 61-66.

Hunt, I. F., Murphy, N. J., Cleaver, A. E., Faraji, B., Swendseid, M. E., Browdy, B. L., Coulson, A. H., Clark, V. A., Settlage, R. H. \& Smith, J. C. (1985). Zinc supplementation during pregnancy in low-income teenagers of Mexican descent: effects on selected blood constituents and on progress and outcome of pregnancy. American Journal of Clinical Nutrition 42, 815-828.

Hunt, I. F., Murphy, N. J., Cleaver, A. E., Faraji, B., Swendseid, M. E., Coulson, A. H., Clark, V. A., Browdy, B. L., Cabalum, M. J. \& Smith, J. C. (1984). Zinc supplementation during pregnancy: effects on selected blood constituents and on progress and outcome of pregnancy in low-income women of Mexican descent. American Journal of Clinical Nutrition 40, 508-521.

Hurley, L. S. \& Swenerton, H. (1966). Congenital malformations resulting from zinc deficiency in rats. Proceedings of the Society for Experimental Biology and Medicine 123, 692-696.

Jackson, M. J., Giugliano, R., Giugliano, L. G., Oliveira, E. F., Shrimpton, R. \& Swainbank, I. G. (1988). Stable isotope metabolic studies of zinc nutrition in slum-dwelling lactating women in the Amazon valley. British Journal of Nutrition 59, 193-203.

Jameson, S. (1976). Effects of zinc deficiency in human reproduction. Acta Medica Scandinavica Suppl. 593, 5-89.

Jameson, S., Burtsröm, M. \& Hellsing, K. (1990). Zinc status in pregnancy. The effect of zinc therapy on perinatal mortality. In International Symposium on Trace Elements in Man and Animals VII, pp. 4.8-4.9 [B. Momcilovic, editor].

Jones, R. B., Keeling, P. W. N., Hilton, P. J. \& Thompson, R. P. H. (1981). The relationship between leucocyte and muscle zinc in health and disease. Clinical Science 60, 237-239.

Karra, M. V., Udipi, S. A., Kirksey, A. \& Roepke, J. L. B. (1986). Changes in specific nutrients in breast milk during extended lactation. American Journal of Clinical Nutrition 43, 495-503.

Khanum, S., Alam, A. N., Anwar, I., Akbar Ali, M. \& Mujibur Rahaman, M. (1988). Effect of zinc supplementation on the dietary intake and weight gain of Bangladeshi children recovering from protein-energy malnutrition. European Journal of Clinical Nutrition 42, 709-714.

King, J. C. (1986). Assessment of techniques for determining human zinc requirements. Journal of the American Dietetic Association 86, 1523-1528.

Kirsten, G. F., Heese, H. de V., Watermeyer, S., Dempster, W. S., Pocock, F. \& Varkvisser, H. (1985). Zinc and copper levels in the breast-milk of Cape Town mothers. South African Medical Journal 68, $402-405$.

Koo, W. W. K., Succop, P. \& Hambidge, K. M. (1989). Serum alkaline phosphatase and serum zinc concentrations in preterm infants with rickets and fractures. American Journal of Diseases of Children 143, $1342-1345$.

Krebs, N. F., Hambidge, K. M., Hagerman, R. J., Peirce, P. L., Johnson, K. M., English, J. L., Miller, L. L. \& Fennessey, P. V. (1988). Effects of pharmacologic doses of folate on zinc absorption and zinc status. In Nutrient A vailability: Chemical and Biological Aspects (Royal Society of Chemistry Special Publication No. 72), pp. 226-228 [D. A. T. Southgate, I. T. Johnson and G. R. Fenwick, editors]. Cambridge: Royal Society of Chemistry.

Krebs, N. F., Hambidge, K. M., Jacobs, M. A. \& Rasbach, J. O. (1985). The effects of a dietary zinc supplement during lactation on longitudinal changes in maternal zinc status and milk zinc concentrations. American Journal of Clinical Nutrition 41, 560-570.

Krebs, N. F., Hambidge, K. M. \& Walravens, P. A. (1984). Increased food intake of young children receiving a zinc supplement. American Journal of Diseases of Children 138, 270-273.

Lehrfeld, J. (1989). High-performance liquid chromatography analysis of phytic acid on a pH-stable, macroporous polymer column. Cereal Chemistry 66, 510-515.

Lönnerdal, B., Sandberg, A.-S., Sandström, B. \& Kunz, C. (1989). Inhibitory effects of phytic acid and other inositol phosphates on zinc and calcium absorption in suckling rats. Journal of Nutrition 119, $211-214$.

McMichael, A. J., Dreosti, I. E., Gibson, G. T., Hartshorne, J. M., Buckley, R. A. \& Colley, D. P. (1982). A prospective study of serial maternal serum zinc levels and pregnancy outcome. Early Human Development 7 , 59-69.

Mahomed, K., James, D. K., Golding, J. \& McCabe, R. (1989). Zinc supplementation during pregnancy: a double blind randomised controlled trial. British Medical Journal 299, 826-830.

Malhotra, A., Fairweather-Tait, S. J., Wharton, P. A. \& Gee, H. (1990). Placental zinc in normal and intra-uterine growth-retarded pregnancies. British Journal of Nutrition 63, 613-621.

Mbofung, C. M. F. \& Atinmo, T. (1987). Trace element nutriture of Nigerians. World Review of Nutrition and Dietetics 51, 105-139.

Meadows, N. J., Ruse, W., Smith, M. F., Day, J., Keeling, P. W. N., Scopes, J. W., Thompson, R. P. H. \& Bloxam, D. L. (1981). Zinc and small babies. Lancet ii, 1135-1137. 
Mills, C. F. (1985). Dietary interactions involving the trace elements. Annual Review of Nutrition 5, $173-193$.

Milne, D. B., Canfield, W. K., Mahalko, J. R. \& Sandstead, H. H. (1984). Effect of oral folic acid supplements on zinc, copper, and iron absorption and excretion. American Journal of Clinical Nutrition 39, 535-539.

Milne, D. B., Ralston, N. V. C. \& Wallwork, J. C. (1985). Zinc content of cellular components of blood: methods for cell separation and analysis evaluated. Clinical Chemistry 31, 65-69.

Monsen, E. R. (1988). Iron nutrition and absorption: dietary factors which impact iron bioavailability. Journal of the American Dietetic Association 88, 786-791.

Moser, P. B., Reynolds, R. D., Acharya, S., Howard, M. P., Andon, M. B. \& Lewis, S. A. (1988). Copper, iron, zinc, and selenium dietary intake and status of Nepalese lactating women and their breast-fed infants. American Journal of Clinical Nutrition 47, 729-734.

Moser-Veillon, P. B. \& Reynolds, R. D. (1990). A longitudinal study of pyridoxine and zinc supplementation of lactating women. American Journal of Clinical Nutrition 52, 135-141.

Mukherjee, M. D., Sandstead, H. H., Ratnaparkhi, M. V., Johnson, L. K., Milne, D. B. \& Stelling, H. P. (1984). Maternal zinc, iron, folic acid, and protein nutriture and outcome of human pregnancy. American Journal of Clinical Nutrition 40, $496-507$.

Murphy, S. P., Beaton, G. H. \& Calloway, D. H. (1992). Estimated mineral intakes of toddlers: predicted prevalence of inadequacy in village populations in Egypt, Kenya, and Mexico. American Journal of Clinical Nutrition 56, 565-572.

National Academy of Sciences. (1991). Nutrition During Pregnancy. Washington, DC: National Academy Press.

National Research Council. (1986). Nutrient Adequacy: Assessment Using Food Consumption Surveys. Washington, DC: National Academy Press.

Neggers, Y. H., Cutter, G. R., Acton, R. T., Alvarez, J. O., Bonner, J. L., Goldenberg, R. L., Go, R. C. P. \& Roseman, J. M. (1990). A positive association between maternal serum zinc concentration and birth weight. American Journal of Clinical Nutrition 51, 678-684.

O’Dell, B. L., Reynolds, G. \& Reeves, P. G. (1977). Analogous effects of zinc deficiency and aspirin toxicity in the pregnant rat. Journal of Nutrition 107, 1222-1228.

Oberleas, D. \& Harland, B. F. (1981). Phytate content of foods: effect on dietary zinc bioavailability. Journal of the American Dietetic Association 79, 433-436.

Okonofua, F. E., Amole, F. A., Emofurieta, W. O. \& Ugwu, N. C. (1989). Zinc and copper concentration in plasma of pregnant women in Nigeria. International Journal of Gynecology and Obstetrics 29, 19-23.

Okonofua, F. E., Isinkaye, A., Onwudiegwu, U., Amole, F. A., Emofurieta, W. A. \& Ugwu, N. C. (1990). Plasma zinc and copper in pregnant Nigerian women at term and their newborn babies. International Journal of Gynecology and Obstetrics 32, 243-245.

Prasad, A. S. \& Cossack, Z. T. (1982). Neutrophil zinc: an indicator of zinc status in man. Transactions of the Association of American Physicians 95, 165-176.

Prasad, A. S., Meftah, S., Abdallah, J., Kaplan, J., Brewer, G. J., Bach, J. F. \& Dardenne, M. (1988). Serum thymulin in human zinc deficiency. Journal of Clinical Investigation 82, 1202-1210.

Prasad, A. S., Miale, A., Farid, Z., Sandstead, H. H. \& Schulert, A. R. (1963). Zinc metabolism in patients with syndrome of iron deficiency anemia, hepatosplenomegaly, dwarfism, and hypogonadism. Journal of Laboratory and Clinical Medicine 61, 537-549.

Prema, K. (1980). Predictive value of serum copper and zinc in normal and abnormal pregnancy. Indian Journal of Medical Research 71, 554-560.

Reddy, N. R., Pierson, M. D., Sathe, S. K. \& Salunkhe, D. K. (1989). Phytates in Cereals and Legumes. Boca Raton, FL: CRC Press.

Rodriguez, A., Venegas, G. V. \& Torres, S. (1991). Zinc supplementation of infants fetal malnourished. In Reunión de la Sociedad Latinoamericana de Oncologia Pediatrica VIII.

Ronaghy, H. S., Reinhold, J. G., Mahloudji, M., Ghavami, P., Spivey Fox, M. R. \& Halsted, J. A. (1974). Zinc supplementation of malnourished schoolboys in Iran: increased growth and other effects. American Journal of Clinical Nutrition 27, 112-121.

Ronaghy, H. S., Spivey Fox, M. R., Garn, S. M., Israel, H., Harp, A., Moe, P. G. \& Halsted, J. A. (1969). Controlled zinc supplementation for malnourished school boys: a pilot experiment. American Journal of Clinical Nutrition 22, 1279-1289.

Rothbaum, R. J., Maur, P. R. \& Farrell, M. K. (1982). Serum alkaline phosphatase and zinc undernutrition in infants with chronic diarrhea. American Journal of Clinical Nutrition 35, 595-598.

Roy, S. K., Behrens, R. H., Haider, R., Akramuzzaman, S. M., Mahalanabis, D., Wahed, M. A. \& Tomkins, A. M. (1992). Impact of zinc supplementation on intestinal permeability in Bangladeshi children with acute diarrhoea and persistent diarrhoea syndrome. Journal of Pediatric Gastroenterology and Nutrition 15, $289-296$.

Roy, S. K., Tomkins, A. M., Haider, R., Behrens, R. H. \& Akramuzzaman, S. M. (1993). The importance of zinc deficiency in stunting and morbidity. International Congress of Nutrition $X V$, p. 713 (Abstr.)

Royal Tropical Institute, Amsterdam. (1987). Weaning Food-a New Approach to Small-scale Weaning Food Production from Indigenous Raw Materials in Tropical Countries, 2nd edn. Amsterdam: Royal Tropical Institute.

Ruz, M., Cavan, K. R., Bettger, W. J. \& Gibson, R. S. (1992). Erythrocytes, erythrocyte membranes, neutrophils and platelets as biopsy materials for the assessment of zinc status in humans. British Journal of Nutrition 68, 515-527. 
Ruz, M., Cavan, K. R., Bettger, W. J., Thompson, L. U., Berry, M. \& Gibson, R. S. (1991). Development of a dietary model for the study of mild zinc deficiency in humans and evaluation of some biochemical and functional indices of zinc status. American Journal of Clinical Nutrition 53, 1295-1303.

Ruz, M. \& Solomons, N. W. (1990). Mineral excretion during acute dehydrating diarrhea treated with oral rehydration therapy. Pediatric Research 27, 170-175.

Sandström, B. (1989). Dietary pattern and zinc supply. In Zinc in Human Biology (International Life Sciences Institute Human Nutrition Reviews), pp. 351-363 [C. F. Mills, editor]. Berlin: Springer-Verlag.

Sandström, B., Almgren, A., Kivistö, B. \& Cederblad, A. (1989). Effect of protein level and protein source on zinc absorption in humans. Journal of Nutrition 119, 48-53.

Sandström, B., Arvidsson, B., Cederblad, A. \& Björn-Rasmussen, E. (1980). Zinc absorption from composite meals. 1. The significance of wheat extraction rate, zinc, calcium, and protein content in meals based on bread. American Journal of Clinical Nutrition 33, 739-745.

Sandström, B. \& Lönnerdal, B. (1989). Promoters and antagonists of zinc absorption. In Zinc in Human Biology (International Life Sciences Institute Human Nutrition Reviews), pp. 57-78 [C. F. Mills, editor]. Berlin: SpringerVerlag.

Schiliro, G., Russo, A., Azzia, N., Mancuso, G. R., Di Gregorio, F. D., Romeo, M. A., Fallico, R. \& Sciacca, S. (1987). Leucocyte alkaline phosphatase (LAP): a useful marker of zinc status in $\beta$-thalassemic patients. American Journal of Pediatric Hematology/Oncology 9, 149-152.

Schlesinger, L., Arevalo, M., Arredondo, S., Diaz, M., Lönnerdal, B. \& Stekel, A. (1992). Effect of a zinc-fortified formula on immunocompetence and growth of malnourished infants. American Journal of Clinical Nutrition 56, $491-498$.

Shrimpton, R., Alencar, F. H., Vasconcelos, J. C. \& Rocha, Y. R. (1985), Effect of maternal zinc supplementation on the growth and diarrhoeal status of breast fed infants. Nutrition Research Suppl. 1, 338S-342S.

Shrimpton, R., Marinho, H. A., Rocha, Y. S. \& Alencar, F. H. (1983). Zinc supplementation in urban Amazonian mothers: concentrations of $\mathrm{Zn}$ and retinol in maternal serum and milk. Proceedings of the Nutrition Society $\mathbf{4 2}$, $122 \mathrm{~A}$

Simmer, K., Ahmed, S., Carlsson, L. \& Thompson, R. P. H. (1990). Breast milk zinc and copper concentrations in Bangladesh. British Journal of Nutrition 63, 91-96.

Simmer, K., Khanum, S., Carlsson, L. \& Thompson, R. P. H. (1988). Nutritional rehabilitation in Bangladesh - the importance of zinc. American Journal of Clinical Nutrition 47, 1036-1040.

Simmer, K., Lort-Phillips, L., James, C. \& Thompson, R. P. H. (1991). A double-blind trial of zinc supplementation in pregnancy. European Journal of Clinical Nutrition 45, 139-144.

Simmer, K. \& Thompson, R. P. H. (1985). Maternal zinc and intrauterine growth retardation. Clinical Science 68, 395-399.

Smit-Vanderkooy, P. D. \& Gibson, R. S. (1987). Food consumption patterns of Canadian preschool children in relation to zinc and growth status. American Journal of Clinical Nutrition 45, 609-616.

Smith, J. C., Udomkesmalee, E. \& Dhanamitta, S. (1993). Effect of vitamin A and zinc supplementation of children in Thailand and Belize, Central America. International Congress of Nutrition XV, p. 618 (Abstr.).

Solomons, N. W. (1981). Zinc and copper in human nutrition. In Nutrition in the 1980s: Constraints on Our Knowledge (Progress in Clinical and Biological Research Vol. 67), pp. 97-127 [N. Selvey and P. L. White, editors]. New York: Alan R. Liss.

Solomons, N. W. (1986). Competitive interaction of iron and zinc in the diet: consequences for human nutrition. Journal of Nutrition 116, 927-935.

Solon, M. A. (1986). Control of vitamin A deficiency by education and the public health approach. In Vitamin A Deficiency and its Control, pp. 285-318 [J. C. Bauernfeind, editor]. New York: Academic Press.

Soltan, M. H. \& Jenkins, D. M. (1982). Maternal and fetal plasma zinc concentration and fetal abnormality. British Journal of Obstetrics and Gynaecology 89, 56-58.

Svanberg, U. \& Sandberg, A. S. (1988). Improved iron availability in weaning foods. In Improved Young Child Feeding in Eastern and Southern Africa: Household Level Food Technology, pp. 366-373 [D. Alnwick, S. Moses and O. G. Schmidt, editors]. Ottawa: International Development Research Center.

Swanson, C. A. \& King, J. C. (1987). Zinc and pregnancy outcome. American Journal of Clinical Nutrition 46, 763-771

Tao, S.-H., Spivey Fox, M. R., Phillippy, B. Q., Fry, B. E., Johnson, M. L. \& Johnston, M. R. (1986). Effects of inositol phosphates on mineral utilization. Federation Proceedings 45, 819.

Thauvin, E., Fusselier, M., Arnaud, J., Faure, H., Favier, M., Coudray, C., Richard, M.-J. \& Favier, A. (1992). Effects of a multivitamin mineral supplement on zinc and copper status during pregnancy. Biological Trace Element Research 32, 405-414.

Thompson, R. P. H. (1991). Assessment of zinc status. Proceedings of the Nutrition Society 50, 19-28.

Tomkins, A., Behrens, R. \& Roy, S. (1993). The role of zinc and vitamin A deficiency in diarrhoeal syndromes in developing countries. Proceedings of the Nutrition Society 52, 131-142.

Torre, M., Rodriguez, A. R. \& Saura-Calixto, F. (1991). Effects of dietary fiber and phytic acid on mineral availability. CRC Critical Reviews in Food Science and Nutrition 30, 1-22.

Turnlund, J. R., King, J. C., Keyes, W. R., Gong, B. \& Michel, M. C. (1984). A stable isotope study of zinc absorption in young men: effects of phytate and $\alpha$-cellulose. American Journal of Clinical Nutrition 40, 1071-1077. 
Tuttle, S., Aggett, P. J., Campbell, D. \& MacGillivray, I. (1985). Zinc and copper in human pregnancy: a longitudinal study in normal primigravidae and in primigravidae at risk of delivering a growth retarded baby. American Journal of Clinical Nutrition 41, 1032-1041.

Udomkesmalee, E., Dhanamitta, S., Sirisinha, S., Charoenkiatkul, S., Tuntipopipat, S., Banjong, O., Rojroongwasinkul, N., Kramer, T. R. \& Smith, J. C. (1992). Effect of vitamin A and zinc supplementation on the nutriture of children in Northeast Thailand. American Journal of Clinical Nutrition 56, 50-57.

Udomkesmalee, E., Dhanamitta, S., Yhoung-Aree, J., Rojroongwasinkul, N. \& Smith, J. C. (1990). Biochemical evidence suggestive of suboptimal zinc and vitamin A status in schoolchildren in Northeast Thailand. American Journal of Clinical Nutrition 52, 564-567.

United Nations. (1991). Some options for improving nutrition in the 1990s. SCN News No. 7, Suppl. 16-18.

Valberg, L. S., Flanagan, P. R. \& Chamberlain, M. J. (1984). Effects of iron, tin, and copper on zinc absorption in humans. American Journal of Clinical Nutrition 40, 536-541.

Walker, A. F. (1990). The contribution of weaning foods to protein-energy malnutrition. Nutrition Research Reviews 3, 25-47.

Wallock, L. M., King, J. C., Hambidge, K. M., English-Westcott, J. E. \& Pritts, J. (1993). Meal-induced changes in plasma, erythrocyte, and urinary zinc concentrations in adult women. American Journal of Clinical Nutrition 58, 695-701.

Walravens, P. A., Chakar, A., Mokni, R., Denise, J. \& Lemonnier, D. (1992). Zinc supplements in breastfed infants. Lancet 340, 683-685.

Walravens, P. A. \& Hambidge, K. M. (1976). Growth of infants fed a zinc supplemented formula. American Journal of Clinical Nutrition 29, 1114-1121.

Walravens, P. A., Hambidge, K. M. \& Koepfer, D. M. (1989). Zinc supplementation in infants with a nutritional pattern of failure to thrive: a double-blind controlled study. Pediatrics 83, 532-538.

Walravens, P. A., Krebs, N. F. \& Hambidge, K. M. (1983). Linear growth of low income preschool children receiving a zinc supplement. American Journal of Clinical Nutrition 38, 195-201.

Wells, J. L., James, D. K., Luxton, R. \& Pennock, C. A. (1987). Maternal leucocyte zinc deficiency at start of third trimester as a predictor of fetal growth retardation. British Medical Journal 294, 1054-1056.

Wise, A. (1983). Dietary factors determining the biological activities of phytate. Nutrition Abstracts and Reviews 53, $791-806$

Xue-Cun, C., Tai-An, Y., Jin-Sheng, H., Qui-Yan, M., Zhi-Min, H. \& Li-Xiang, L. (1985). Low levels of zinc in hair and blood, pica, anorexia, and poor growth in Chinese preschool children. American Journal of Clinical Nutrition 42, 694-700.

Zlotkin, S. H. \& Casselman, C. (1988). Diurnal variation in urinary zinc excretion and the use of zinc/Cr ratio from random urine samples to monitor zinc status. Canadian Federation of Biological Sciences, Quebec, p. 624 (Abstr.). 